\title{
THE NEED OF A NEW MANAGEMENT REGARDING THE CONTRADICTORY EAST-WEST EUROPEAN CAPITAL AND LABOUR FLOWS. A REGIONAL WELFARE APPROACH
}

\author{
Romeo Victor IONESCU ${ }^{1}$, Monica Laura ZLATI ${ }^{2}$, \\ Valentin Marian ANTOHI ${ }^{3,4}$ \\ ${ }^{1}$ Department of Administrative Sciences and Regional Studies, Faculty of Social, Political and \\ Legal Sciences, Dunarea de Jos University, 111-th Domneasca str., 800201, Galati, Romania \\ ${ }^{2}$ Department of Accounting, Audit and Finance, Stefan cel Mare University, Suceava, Romania \\ ${ }^{3}$ Department of Business Administration, Faculty of Economics and Business Administration, \\ Dunarea de Jos University, Nicolae Balcescu Street No. 59-61, 800001, Galati, Romania \\ ${ }^{4}$ Faculty of Economic Sciences and Business Administration, Transylvania University, \\ Colina Universitatii str. No. 1, Brasov, Romania
}

Received 13 May 2021; accepted 19 October 2021; first published online 04 March 2022

\begin{abstract}
The paper addresses an extremely current phenomenon: migration in opposite directions of FDI and labour, in context with the permanent need for economic growth and welfare. The analysis is carried out over a period of 12 years, in the context of setting objectives and working hypotheses regarding the realization of a correlation model of phenomena and optimization of migration flows in order to obtain welfare through economic development. The results of the research will reflect the relevance of the aggregation of the two migratory flows (FDI and labour) in order to obtain the financial leverage effect and the economic welfare in the analysed regions (EU, Germany and Romania).The conclusions of the study reflect the relevance of the method, the validity of the model and its relevance for the decision forums interested in the economic development and in increasing the population welfare.
\end{abstract}

Keywords: Foreign Direct Investment, labour flows, optimal area of intersection, economic growth, development, labour welfare, migration flows.

JEL Classification: F43, C01, F16.

\section{Introduction}

We consider this approach necessary and opportune based on the scientific interest aroused by this very dynamic field, considering the perspectives of the European development. Moreover, the existence of the gap in the literature we have studied is another argument in supporting this scientific approach that is based on the welfare-relocation-allocation paradigm.

*Corresponding author. E-mail: valentin_antohi@yahoo.com

Copyright (c) 2022 The Author(s). Published by Vilnius Gediminas Technical University

This is an Open Access article distributed under the terms of the Creative Commons Attribution License (http://creativecommons. org/licenses/by/4.0/), which permits unrestricted use, distribution, and reproduction in any medium, provided the original author and source are credited. 
Both aspects are European desideratum in most of the development strategies adopted by the European forums.

The present European Union is characterized by significant socio-economic disparities between Member States. The mission of supranational decision makers is to create a homogeneous system that allows generation and dissemination of economic welfare for all Member States. The cohesion policy proves to be far less than political expectations, amid labour and capital migration challenges, in the context of people and goods circulation liberalization and the market mechanisms manifestation. As a result, the demand of labour and capital meets the supply at the most attractive point. These phenomena are directly influenced by the consequences of globalization, so the migratory phenomenon multiplies by the influence of external factors, putting pressure on labour supply in the EU developed countries.

On the other hand, the economic disparities within the EU allow the migration of capital from developed Member States to the least developed, in search of cheap (material and human) resources. The complexity of the phenomenon affects the single market, in the sense of accentuating the existing disparities.

A counter-flow is represented by the migrant labour factor from the less developed EU states in other EU and non-EU developed states. The migratory phenomenon also affects public policies on social protection in developed countries, which face additional needs in terms of both social assistance and the provision of minimum health conditions for all residents.

The immediate effect of these phenomena was a reduction of 60 billion euros in EU FDI flows to the rest of the world in 2018 compared to the previous year, when they amounted to 301 billion euros (European Commission, 2019a).

The global picture established in terms of measures to the world economy sustainability increasing reflects, by the level of the 17 objectives set out in Agenda 2030, the next state of affairs at the level of 2018 (United Nations, 2019):

Goal 1: measures regarding poverty elimination. There is an increase in national security rates in terms of global poverty eradication, with the figure that only $11 \%$ of the world's population lives below the poverty line today.

Goal 8: sustainable economic development. The global economic picture reflects a GDP growth per capita of $1.3 \%$ in 2016, compared with an average of $1.7 \%$ during $2010-2016$.

Goal 9: infrastructure. It has seen a global improvement in terms of allocations for the creation of transport facilities that favour the sustainable development.

Goal 10: Reducing inequalities within and between states. It was supported by the introduction of zero tariffs for exports from underdeveloped countries, which led to the migration of capital flows to these areas where the labour force is cheaper, given the prerequisites for competitive advantage for investors.

The analysis in this paper covers only 4 goals, which are compatible to our approach. In the presented above context, the research team proposes as goal to develop a model (MILM) for assessing the connections between labour supply and capital supply, respectively labour demand and capital demand across the EU. The model also takes into account the global evolutions of capital and labour migratory factors and seeks to define the optimal convergence 
zone of these two economic resources in order to create the prerequisites for sustainable development of the less developed regions. The study covers the EU, an area characterized by economic disparities and the capital and labour migration, as well.

The general aim of the research is to develop the welfare - relocation - allocation paradigm in order to stimulate investment, labour allocation and migration policies in line with the latest global developments. The specific aim is the analysis perspective that clarifies the issues triggering the contradictory flows between FDI and labour.

In order to achieve the proposed goal, the following objectives are set:

O1: identifying models of economic development and welfare at the level of current trends recognized by the literature;

O2: the conceptualization of the statistical correlation model (Migrant Investment and Labour Model - MILM) in direct correlation with sustainable development and welfare;

O3: connecting model MILM to the potential investment development factors;

O4: an impact study to optimize the congruent use of migratory capital and labour as an engine for regional economic development and welfare.

The optimal convergence zone is that resulting from the intersection of FDI and labour antagonistic fluxes. The labour flows come from lower developed Member States and are focused on greater wages and better social conditions. These flows are multiplied by the refugees' flows, as well. The EU FDI migrate from high developed EU economies to lower developed EU economies in order to find cheaper trained labour and better economic facilities. There are non-EU FDI with the same destination, as well.

The intersection of these above four flows categories creates the optimal area in Figure 1. This area can belong to a lower developed EU economy, to a developed EU economy or to a trans-border region.

The used methods were selected from the possible statistical methods, taking into account the relational nature of the data, constituting the data panels after processing the official information given by the Eurostat. The reliability of the methods was tested both by validation on the logical scheme and by statistical validation. These allow the validity of the model to be demonstrated in a transparent manner, using established statistical programs (SPSS and Gretl) and modelling procedures based on multiple linear regression functions and Pearson correlations.

The model introduced in this paper is focused on finding the optimal area location and on maximization of this area under economic competitiveness conditions.

The present paper is structured as follows: Introduction, Theoretical framework, Methodology, Results and Discussion, Conclusions.

\section{Theoretical framework}

There are a lot of theoretical and practical approaches regarding the connections between FDI and labour and their support for economic development.

The current state of knowledge shows that the connection between FDI and the global organization of economic activity through multinational companies is the subject of an extensive meta-analysis approach carried out in 2020 (Paul \& Feliciano-Cestero, 2021). More than 500 published research articles in the last 50 years have been investigated. Connections 
were made between theoretical models and contributions to improving FDI perception. Based on this research, we notice a contextual structuring of the variables depending on the way in which FDI is formed and applied, as well as depending on the factors and variables that influence the FDI's organizational framework.

Under a global perspective, on the principle of global FDI networks, another research (Bolívar et al., 2019) presents the economic performance and the association with certain FDI partners employing social network analysis. This approach has a degree of novelty, approaches FDI stocks from 229 economies sheds light on the interactions of the global FDI network within its singular context of country-level determinants, its after-effects, internal patterns, and relationship with the network of Bilateral Investment Treaties (BITs).

Some authors have approached the FDI analysis with the influences on the financial markets (research applied on US financial markets in 2020 by Yavas and Malladi (2020)), which investigates the connection between the two elements, investment decisions and market response through capitalization and volatility. The investment decision of the global economic entities is placed under risk and uncertainty factors, against the background of volatility and variable investment recovery rates in the destination country. The study is based on a consistent research covering 1994-2018, a period that presented phenomena of volatility, inflation and international risk able to confirm the research result, namely the fact that the higher equity market valuations resulting in cheaper home country financing.

Other authors have studied FDI as an intrinsic factor of the economic growth (Pradhan et al., 2019). The research was conducted using a sample of the G-20 countries over the period 1970-2016. Methodologically, a vector model of error correction was designed in order to be used for the causal redirection of FDI in order to grow.

From the economic growth point of view, an effect is noticeable on the labour market. In the context of the global economy, the labour market is often influenced by migration in the developing countries. In 2019, a study on trade, migration and productivity in the Chinese economy (Tombe \& Zhu, 2019) shows that there is an interdependence between the three areas, and the costs of exporting skilled labour to the detriment of the local economy can be significant and difficult to manage over time. Thus, the authors show that, during 2000-2019, the process of managing these costs was a difficult success, and the impact area was covered by the costs' management on internal trade and labour migration than by external trade cost.

This phenomenon has been addressed by Chinese researchers in 2020 (Rong et al., 2020) in relation to FDI, as well. The authors found, contrary to the current opinion circulated at the time of publication, that the FDI infusion can improve the employment rate and its qualification in a proportion of $21 \%$, to an increase of FDI of $1 \%$. This study covered the period 2000-2015, targeted 30 Chinese provinces and quantified the effects of FDI and labour market flexibility under the influence of FDI. This study represents a real challenge for us.

Another research, conducted at EU post-Brexit level, investigates the relationship between trade, government performance and migration at the level of 23 Member States during 1998-2017. According to the regression analysis, the authors showed that the migration is relatively negative for the trade, but it is primarily negative for the government performance (Adedoyin et al., 2021). As a result, the EU regional decision factors have to improve regulatory institutions in order to increase the regional export sector and to integrate migrants able to work in this sector. 
All of the above scientific approaches are based on "classical" research; the synthesis of which is presented in Table 1.

Table 1. Theoretical models related to FDI and labour flows in Europe (source: authors' contribution)

\begin{tabular}{|c|c|c|c|}
\hline \multirow{3}{*}{$\begin{array}{l}\quad \text { Author } \\
\text { Boghean C. } \\
\text { \& State M. } \\
\text { (Boghean \& } \\
\text { State, 2015) }\end{array}$} & \multirow{3}{*}{$\frac{\text { Year }}{2015}$} & \multicolumn{2}{|r|}{ Observations } \\
\hline & & Model & $\begin{array}{l}\text { - the connection between FDI and labour productivity in the EU } \\
\text { based on an impact analysis during } 2000-2012 \text {. }\end{array}$ \\
\hline & & Impact & $\begin{array}{l}\text { Still actual, with few adjustments: } \\
\text { - the correlation model used under Spearman coefficient, high- } \\
\text { lights that the correlation ratio is one directly proportional and } \\
\text { with high statistical significance; } \\
\text { - the policies to attract FDI based on the Spearman coefficient are } \\
\text { sustainable in developed countries. }\end{array}$ \\
\hline \multirow[t]{2}{*}{$\begin{array}{l}\text { Meunier S. } \\
\text { (Meunier, 2017) }\end{array}$} & \multirow[t]{2}{*}{2017} & Model & $\begin{array}{l}\text { - a case analysis on the policy of attracting FDI in the light of the } \\
\text { Treaty of Lisbon. }\end{array}$ \\
\hline & & Impact & $\begin{array}{l}\text { Still in use with major adjustments: } \\
\text { - a theoretical approach, through the study of the specialized lit- } \\
\text { erature; } \\
\text { - highlighting regional contrasts within the EU regarding FDI } \\
\text { policies. }\end{array}$ \\
\hline \multirow[t]{2}{*}{$\begin{array}{l}\text { Pegkas P. } \\
\text { (Pegkas, 2015) }\end{array}$} & \multirow[t]{2}{*}{2015} & Model & $\begin{array}{l}\text { - economic growth model based on the connections between FDI } \\
\text { and economic growth; } \\
\text { - the dynamic assessment of the FDI influence on the economic } \\
\text { growth in the Eurozone states, based on GDP elasticity, econo- } \\
\text { metric modelling by the least square's method. }\end{array}$ \\
\hline & & Impact & $\begin{array}{l}\text { Still in use with few adjustments: } \\
\text { - the model was statistically demonstrated on the basis of dynamic } \\
\text { analysis, resulting in higher static significance values than in the } \\
\text { classic models. }\end{array}$ \\
\hline \multirow{2}{*}{$\begin{array}{l}\text { Simionescu M. } \\
\text { (Simionescu, } \\
\text { 2016) }\end{array}$} & \multirow[t]{2}{*}{2016} & Model & $\begin{array}{l}\text { - economic growth model based on economic sustainable growth } \\
\text { and FDI during the economic crisis across the EU. }\end{array}$ \\
\hline & & Impact & $\begin{array}{l}\text { Actual with minor adjustments: } \\
\text { - by statistical analysis, the FDI absorption vulnerabilities with } \\
\text { extrapolation on economic growth are pointed out, analyzing } \\
\text { the dependency curve between GDP rate and FDI; } \\
\text { - the impact of the study is the identification of vulnerability } \\
\text { zones and measures to strengthen the economic environment } \\
\text { in order to achieve economic growth through legislative and fis- } \\
\text { cal incentives; } \\
\text { - the author does not consider the effects of the bureaucratic ap- } \\
\text { paratus and the infrastructure aspects. }\end{array}$ \\
\hline \multirow{2}{*}{$\begin{array}{l}\text { Ebell M., Hurst } \\
\text { I., \& Warren J. } \\
\text { (Ebell et al., } \\
\text { 2016) }\end{array}$} & \multirow[t]{2}{*}{2016} & Model & FDI analysis in the context of the Brexit. \\
\hline & & Impact & $\begin{array}{l}\text { Actual without adjustments: } \\
\text { - the authors use WTO data to conceptualize a logarithmic impact } \\
\text { model of FDI on UK foreign trade; } \\
\text { - the findings of the study reflect that, on short term, Brexit will } \\
\text { have a profound disturbing effect on UK development, materi- } \\
\text { alized by devaluing the pound. On long run, according to the } \\
\text { study, the trend will be rectified starting to 2025; } \\
\text { - the model is dedicated and, as a result, it is difficult to obtain the } \\
\text { generalization of its use. }\end{array}$ \\
\hline
\end{tabular}


Continue of Table 1

\begin{tabular}{|c|c|c|c|}
\hline \multirow{3}{*}{$\begin{array}{l}\quad \text { Author } \\
\text { Antonescu D. } \\
\text { (Antonescu, } \\
\text { 2015) }\end{array}$} & \multirow{3}{*}{2015} & \multicolumn{2}{|r|}{ Observations } \\
\hline & & Model & $\begin{array}{l}\text { - the model analyses FDI at regional level through the case study } \\
\text { Romania at NUTS } 2 \text { level. }\end{array}$ \\
\hline & & Impact & $\begin{array}{l}\text { Still in use with major adjustments: } \\
\text { - there is the regional proximity dependence of FDI as a regional } \\
\text { development factor with direct effect on GDP; } \\
\text { - there are } 2 \text { development areas (east and west) in Romania and } \\
\text { the developed area has a higher capacity to attract FDI. }\end{array}$ \\
\hline \multirow[t]{2}{*}{$\begin{array}{l}\text { Campos N. F. } \\
\text { (Bruno et al., } \\
\text { 2017) }\end{array}$} & \multirow[t]{2}{*}{2017} & Model & $\begin{array}{l}\text { - FDI analysis in the relationship between the UK and the EU } \\
\text { through Brexit prism; } \\
\text { - managing the migration impact on the EU market; } \\
\text { - analysis of the post-Brexit commercial relationships integration. }\end{array}$ \\
\hline & & Impact & $\begin{array}{l}\text { Curently in use, high impact: } \\
\text { - developing } 2 \text { evolving scenarios of the EU-UK post-Brexit trade } \\
\text { partnership; } \\
\text { - making it clear that deep economic integration is difficult to } \\
\text { reach outside the EU. }\end{array}$ \\
\hline \multirow{2}{*}{$\begin{array}{l}\text { San Roman } \\
\text { V. M., Bengoa } \\
\text { M., \& Sanchez- } \\
\text { Robles B. } \\
\text { (Martínez-San } \\
\text { Román et al., } \\
\text { 2016) }\end{array}$} & \multirow[t]{2}{*}{2015} & Model & $\begin{array}{l}\text { - an analysis model based on the study of literature between FDI } \\
\text { and commercial integration; } \\
\text { - FDI flows are more consistent in the presence of the investment } \\
\text { know-how. }\end{array}$ \\
\hline & & Impact & $\begin{array}{l}\text { Curently in use, high impact: } \\
\text { - the authors use the statistical modeling technique to establish } \\
\text { congruent relations between FDI and trade; } \\
\text { - there are impact areas for which the FDI attractiveness increases } \\
\text { relative to biased flows calculated within the EU. }\end{array}$ \\
\hline \multirow[t]{2}{*}{$\begin{array}{l}\text { Tang D. (Tang, } \\
\text { 2017) }\end{array}$} & \multirow[t]{2}{*}{2017} & Model & $\begin{array}{l}\text { - FDI migration in the EU, in the countries of central and eastern } \\
\text { Europe, during 1994-2012. }\end{array}$ \\
\hline & & Impact & $\begin{array}{l}\text { Curently in use, high impact: } \\
\text { - the proposed logarithmic model assesses the effects of financial } \\
\text { development on FDI; } \\
\text { - the model takes into account indicators related to bank credit } \\
\text { variables, stock market size, labor cost, trade open, etc.; } \\
\text { - the model does not take into account the effects of bureaucracy } \\
\text { and the infrastructure issues. }\end{array}$ \\
\hline \multirow{2}{*}{$\begin{array}{l}\text { Alama-Sabater } \\
\text { L., Heid B., } \\
\text { Jimenez- } \\
\text { Fernandez E., \& } \\
\text { Marquez-Ramos } \\
\text { L. (Alamá- } \\
\text { Sabater et al., } \\
\text { 2017) }\end{array}$} & \multirow{2}{*}{2016} & Model & $\begin{array}{l}\text { - spatial econometric model of interaction between aggregate FDI } \\
\text { and stock. }\end{array}$ \\
\hline & & Impact & $\begin{array}{l}\text { Curently in use, high impact: } \\
\text { - gravitational model according to the theory of LeSage and } \\
\text { Thoman Agnan; } \\
\text { - the findings of the study highlight the fact that developed econo- } \\
\text { mies are more attractive from the FDI point of view. }\end{array}$ \\
\hline \multirow{2}{*}{$\begin{array}{l}\text { Paunica M., } \\
\text { Manole A., } \\
\text { Motofei C., \& } \\
\text { Tanase G. L. } \\
\text { (Paunica et al., } \\
\text { 2018) }\end{array}$} & \multirow[t]{2}{*}{2018} & Model & $\begin{array}{l}\text { - statistical analysis of the globalization impact using foreign } \\
\text { trade, employment and investment; case study Romania; } \\
\text { - determining a global economic behaviour according to the } \\
\text { above variables. }\end{array}$ \\
\hline & & Impact & $\begin{array}{l}\text { Curently in use, average impact: } \\
\text { - the economic growth is closely related to the evolution of the } \\
\text { globalization indicators, and the effects of the indicators' modi- } \\
\text { fication are cyclically transposed on the economic crisis' phases. }\end{array}$ \\
\hline
\end{tabular}


Continue of Table 1

\begin{tabular}{|c|c|c|c|}
\hline \multirow{3}{*}{\begin{tabular}{l}
\multicolumn{1}{c}{ Author } \\
Dhingra S., \\
Ottaviano G., \\
Rapport V., \\
Sampson T., \\
\& Thomas C. \\
(Dhingra et al., \\
2018)
\end{tabular}} & \multirow{3}{*}{$\frac{\text { Year }}{2017}$} & \multicolumn{2}{|r|}{ Observations } \\
\hline & & Model & $\begin{array}{l}\text { - the analysis of investment flows from a post-Brexit perspective } \\
\text { based on UK foreign trade; } \\
\text { - the analysis is structured on activity domains in relation to the } \\
\text { labour force engaged in foreign-owned-affiliates. }\end{array}$ \\
\hline & & Impact & $\begin{array}{l}\text { Curently in use, high impact: } \\
\text { - the effects of the Brexit are seen as having a potentially nega- } \\
\text { tive impact on welfare in the UK, which will be affected from } \\
\text { the global trade point of view, by increasing economic costs and } \\
\text { increasing political sovereignty, as well. }\end{array}$ \\
\hline \multirow[t]{2}{*}{$\begin{array}{l}\text { Delevic U. \& } \\
\text { Heim I. (Delevic } \\
\text { \& Heim, 2017) }\end{array}$} & \multirow[t]{2}{*}{2017} & Model & $\begin{array}{l}\text { Analysing the process of European integration for } 16 \\
\text { under transition countries, which demonstrates the directly } \\
\text { proportional relationship between FDI inflows and the access to } \\
\text { the EU. }\end{array}$ \\
\hline & & Impact & $\begin{array}{l}\text { Curently in use, low impact: } \\
\text { - relative impact because the discriminatory aspect of FDI incen- } \\
\text { tives and the procedure for locating these investments were not } \\
\text { measured; } \\
\text { - the study is applied on Member States and non-EU members. }\end{array}$ \\
\hline \multirow{2}{*}{$\begin{array}{l}\text { Camarero M., } \\
\text { Gomez-Herrera } \\
\text { E., \& Tamarit C. } \\
\text { (Camarero et.al., } \\
\text { 2018) }\end{array}$} & \multirow{2}{*}{2018} & Model & $\begin{array}{l}\text { - an observational study on } 28 \text { states during } 1990-2013 \text {, for high- } \\
\text { lighting a spatial model for analysing the side effects of the per- } \\
\text { formance indicators affecting trade and FDI in the EU, from the } \\
\text { perspective of the EMU establishment. }\end{array}$ \\
\hline & & Impact & $\begin{array}{l}\text { Actually in use, high impact: } \\
\text { - high impact, considering the size of the study, the statistical in- } \\
\text { vestigation procedures and the corrections applied to the spatial } \\
\text { model that identifies FDI flows as a position in the EU stabiliza- } \\
\text { tion from the trade point of view. }\end{array}$ \\
\hline \multirow[t]{2}{*}{$\begin{array}{l}\text { Dellis K., } \\
\text { Sondermann D, } \\
\text { \& Vansteenkiste } \\
\text { I. (Dellis et al., } \\
\text { 2017) }\end{array}$} & \multirow[t]{2}{*}{2017} & Model & $\begin{array}{l}\text { - the FDI flows are analysed from the economic perspective of } 21 \\
\text { OECD states during 2005-2014; } \\
\text { - indicators of influence on FDI absorption are established, such } \\
\text { as: the quality of the Labour / goods market ratio, business con- } \\
\text { ditions, the quality of the political institutions. }\end{array}$ \\
\hline & & Impact & $\begin{array}{l}\text { Curently in use, high impact: } \\
\text { - ignificant impact; there is an interdependence between the } \\
\text { short-term factors and the attraction of FDI flows, the decisive } \\
\text { factor being attributed to the macroeconomic structural con- } \\
\text { ditions' improvement of an economy from the Eurozone that } \\
\text { wants to increase the FDI's absorption. }\end{array}$ \\
\hline \multirow[t]{2}{*}{$\begin{array}{l}\text { Comes C.A., } \\
\text { Bunduchi } \\
\text { E., Vasile V., } \\
\text { \& Stefan D. } \\
\text { (Comes et al., } \\
\text { 2018) }\end{array}$} & \multirow[t]{2}{*}{2018} & Model & $\begin{array}{l}\text { - the analysis of the FDI impact on the economic growth in the } \\
\text { Central and Eastern European countries with GDP / capita less } \\
\text { than } 25,000 \text { USD; } \\
\text { - there is a direct relation between the decrease of FDI absorption } \\
\text { and the decrease of the economic growth, based on short-term } \\
\text { factors (decrease of GDP, remittance entries). }\end{array}$ \\
\hline & & Impact & $\begin{array}{l}\text { Curently in use, low impact: } \\
\text { - low impact, due to the quantitative limitations (countries with } \\
\text { GDP less than 25,000 USD / capita) and qualitative limitations } \\
\text { (few economic indicators used in the presented regressions), as } \\
\text { well. }\end{array}$ \\
\hline
\end{tabular}


Continue of Table 1

\begin{tabular}{|c|c|c|c|}
\hline \multirow{3}{*}{\begin{tabular}{l|}
\multicolumn{1}{c|}{ Author } \\
Bruno R. L. \\
\& Cipollina \\
M. (Bruno \& \\
Cipollina, 2018)
\end{tabular}} & \multirow{3}{*}{$\begin{array}{c}\text { Year } \\
2017\end{array}$} & \multicolumn{2}{|r|}{ Observations } \\
\hline & & Model & $\begin{array}{l}\text { - a reference study for the analysed phenomenon, the authors con- } \\
\text { ducting a meta-analysis of the development impact through the } \\
\text { FDI attraction in the Member States before and after the EU15. }\end{array}$ \\
\hline & & Impact & $\begin{array}{l}\text { Curently in use, high impact: } \\
\text { - combining and explaining the variables that influence the FDI's } \\
\text { development, including the spin-over effect at the Member } \\
\text { States' level at the same time as the EU enlargement process; } \\
\text { - mathematical identification, by regression, of the influence indi- } \\
\text { cators on FDI and economic performance, indicators which are } \\
\text { then tested for each Member State, using the EU15 inflection point. }\end{array}$ \\
\hline \multirow[t]{2}{*}{$\begin{array}{l}\text { Tan B. W., } \\
\text { Goh S. K., \& } \\
\text { Wong K. N. } \\
\text { (Tan et al., } \\
\text { 2016) }\end{array}$} & \multirow[t]{2}{*}{2016} & Model & $\begin{array}{l}\text { - the authors found other FDI's effects than domestic savings and } \\
\text { investment; } \\
\text { - the conclusions of this research can support political decisions } \\
\text { of the emerging economies in order to achieve inclusive growth } \\
\text { and sustainable development. }\end{array}$ \\
\hline & & Impact & $\begin{array}{l}\text { Curently in use, average impact: } \\
- \text { a great limitation of this approach consists in the low number of } \\
\text { economies taken into account for this analysis (ASEAN region). }\end{array}$ \\
\hline \multirow[t]{2}{*}{$\begin{array}{l}\text { Raza S. A. } \\
\text { (Raza, 2015) }\end{array}$} & \multirow[t]{2}{*}{2015} & Model & $\begin{array}{l}\text { - the analysis in this paper points out the bidirectional causal re- } \\
\text { lationship of FDI and workers' remittances with private savings } \\
\text { in a particular economy (Pakistan); } \\
\text { - the analysis is based, for the first time in Pakistan on long an- } \\
\text { nual time series data and more rigorous econometric techniques. }\end{array}$ \\
\hline & & Impact & $\begin{array}{l}\text { Curently in use, low impact: } \\
\text { - the greatest limitation consists in analysing a single economy, } \\
\text { with no connection to the other economies at least from the } \\
\text { same region; } \\
\text { - even the author recognized that his research has to be extend to } \\
\text { other countries which cover the South Asia. }\end{array}$ \\
\hline \multirow[t]{2}{*}{$\begin{array}{l}\text { Hanclova J., } \\
\text { Doucek P., } \\
\text { Fischer J., } \\
\text { \& Vltavska K. } \\
\text { (Hanclova et al., } \\
\text { 2015) }\end{array}$} & \multirow[t]{2}{*}{2015} & Model & $\begin{array}{l}\text { - the research covers the economic growth and its components } \\
\text { taking into account the Member States grouped into two clusters } \\
\text { (EU15 and EU12); } \\
\text { - the main result of this research is that a drop in GDP growth in } \\
\text { one cluster was a result of the slower growth of non-ICT capital } \\
\text { and total factor productivity in the other cluster. }\end{array}$ \\
\hline & & Impact & $\begin{array}{l}\text { Curently in use, average impact: } \\
\text { - the paper's results are not the same with other researches in the } \\
\text { same field as a result of the used methods and economic models; } \\
\text { - on the other hand, the use of a Cobb-Douglas function for the } \\
\text { analysis is not the best way to obtain relevant resuls. }\end{array}$ \\
\hline \multirow[t]{2}{*}{$\begin{array}{l}\text { Josifidis K., } \\
\text { Supic N., Pucar } \\
\text { E. B., \& Srdic S. } \\
\text { (Josifidis et al., } \\
\text { 2014) }\end{array}$} & \multirow[t]{2}{*}{2013} & Model & $\begin{array}{l}\text { - the authors made a real distinction between "favourable" and } \\
\text { "unfavourable" migrations and immigration; } \\
\text { - as a result, the most developed Member States can be considered } \\
\text { a magnet for the favourable immigration. }\end{array}$ \\
\hline & & Impact & $\begin{array}{l}\text { Curently in use, average impact: } \\
\text { - the specific case of migration inside EU pointed out that there } \\
\text { is no strong; } \\
\text { - evidence that migrations had a negative linear impact on earn- } \\
\text { ings and employment of domestic workers; } \\
\text { - the fear of the Member States that migration will affect their } \\
\text { welfare is not economically rational. }\end{array}$ \\
\hline
\end{tabular}


End of Table 1

\begin{tabular}{|c|c|c|c|}
\hline \multirow{3}{*}{\begin{tabular}{l}
\multicolumn{1}{c}{ Author } \\
Baškot B. \\
(Baškot, 2020)
\end{tabular}} & \multirow{3}{*}{$\frac{\text { Year }}{2020}$} & \multicolumn{2}{|r|}{ Observations } \\
\hline & & Model & $\begin{array}{l}\text { - the model takes into account the labor factor / young labor fac- } \\
\text { tor under the incidence of shocks caused by migratory capital } \\
\text { flows; } \\
\text { - the reaction of the total and young labor is a positive one to- } \\
\text { wards the capital migration; } \\
\text { - the case study covers Bosnia and Herzegovina. }\end{array}$ \\
\hline & & Impact & $\begin{array}{l}\text { Curently in use, high impact: } \\
\text { - the author is in a slightly different position from that of this } \\
\text { analysis, but still confirms the dependence relationship between } \\
\text { FDI and labor. }\end{array}$ \\
\hline \multirow{2}{*}{$\begin{array}{l}\text { Șerban A. C., } \\
\text { Aceleanu M. I., } \\
\text { Dospinescu A. } \\
\text { S., Tirca D.-M., } \\
\text { \& } \\
\text { Novo-Corti I. } \\
\text { (Serban et al., } \\
2020 \text { ) }\end{array}$} & \multirow[t]{2}{*}{2020} & Model & $\begin{array}{l}\text { - the authors use a dynamic modeling of the labor migration phe- } \\
\text { nomenon using its characteristic variables; } \\
\text { - the results of the qualified labor migration over the host state } \\
\text { consist in its economic growth. }\end{array}$ \\
\hline & & Impact & $\begin{array}{l}\text { Curently in use, high impact: } \\
\text { - migration is a continuous source of economic growth for ben- } \\
\text { eficiary and supplier countries; } \\
\text { - the process of permanent changes in the migration policies leads } \\
\text { to a permanent review of their approach; }\end{array}$ \\
\hline \multirow[t]{2}{*}{$\begin{array}{l}\text { Lewandowska } \\
\text { A., \& Stopa } \\
\text { M. (2020). } \\
\text { (Lewandowska } \\
\text { \& Stopa, 2020) }\end{array}$} & 2020 & Model & $\begin{array}{l}\text { - the authors analyze the labour's formal education and skills } \\
\text { through the prism of } 95 \text { directions of education on three differ- } \\
\text { ent levels each: basic and secondary vocational education, higher } \\
\text { education and professional courses; } \\
\text { - the whole analysis is based on a survey conducted on a represen- } \\
\text { tative sample of Polish citizens of the working age. }\end{array}$ \\
\hline & & Impact & $\begin{array}{l}\text { Curently in use, high impact: } \\
\text { - the innovative qualifications are often chosen by men; } \\
\text { - innovation implies rarely the cooperation with third parties; } \\
\text { - the super-skilled and innovative labour will freely change work- } \\
\text { places and professions on the Polish labor market. }\end{array}$ \\
\hline \multirow{2}{*}{$\begin{array}{l}\text { Mihi-Ramirez } \\
\text { A., Arteaga- } \\
\text { Ortíz J., \& } \\
\text { Ojeda- } \\
\text { González S. } \\
\text { (Mihi-Ramirez } \\
\text { et al., 2019) }\end{array}$} & 2019 & Model & $\begin{array}{l}\text { - the authors use a Linear Mixed Model in order to analyze the } \\
\text { connections between FDI, emigration and immigration after the } \\
\text { great economic recession; } \\
\text { - the analysis covers } 112 \text { countries connected by migratory and } \\
\text { investment chains to Spain. }\end{array}$ \\
\hline & & Impact & $\begin{array}{l}\text { Curently in use, high impact: } \\
\text { - FDI and migration represent the two sides of the same coin; } \\
\text { - the proactive migration policies have to cover: support inte- } \\
\text { gration in host countries, support for migrants' return to their } \\
\text { homes and trade agreements able to stabilize the migrant flows; } \\
\text { - the emigration process is supported by lower FDI. }\end{array}$ \\
\hline \multirow[t]{2}{*}{$\begin{array}{l}\text { Lazutka R. } \\
\text { Juška A., \& } \\
\text { Navicke J. } \\
\text { (Lazutka et al., } \\
\text { 2018) }\end{array}$} & \multirow[t]{2}{*}{2018} & Model & $\begin{array}{l}\text { - the authors analyze the neoliberal development model imple- } \\
\text { mented in Lithuania after 1991; } \\
\text { - the economic indicators of the model are labour and capital in } \\
\text { connectetion to the economic growth. }\end{array}$ \\
\hline & & Impact & $\begin{array}{l}\text { Curently in use, high impact: } \\
\text { - the neoliberal model has to be updated in Lithuania because it } \\
\text { brought inequalities in income and wealth. }\end{array}$ \\
\hline
\end{tabular}


The above literature review points out at least two important aspects. First, the importance of the connection between FDI, labour and economic development. Second, the multitude of proposed solutions able to increase economic performance in this context.

This is why the present research proposes a new approach regarding the triple connection FDI-labour-economic development, starting from the economic environment reality. This approach was not used till now, even that it is based on the above literature review. The same situation is that related to the model proposed in this paper, which is absolutely new.

\section{Methodology}

The present scientific approach is initiated according to the hypothesis that the current EU is facing to strong migration flows of capital and labour. The basic idea is to determine an economically optimal area where outgoing labour flows meet incoming FDI flows. This optimal area can be located within a less developed Member State, within a developed Member State or in another EU region. The delimitation of the optimal area can be done with the help of the model proposed by us in this work. The delimitation criteria for this area are those regarding economic efficiency. Finally, the model is tested on two EU economies: Germany and Romania, which have antithetical economic performances.

The prospective analysis for the model elaboration used public data taken from the United Nations Organisation and Eurostat reports regarding those macroeconomic indicators used in the proposed model, including those for the special section on migration analysis in and from the EU.

For the impact components' evaluation, the analysis takes into account the values reported by the same institutions regarding the regional indexes of global competitiveness on the 10 objectives proposed by the World Economic Forum regarding the pillars of competitiveness, as they appear in the respective report (Schwab, 2018).

The specific aim is the analysis perspective that clarifies the issues triggering the contradictory flows between FDI and labour.

The analysed data cover a 10-year horizon, of which 3 forecasted years. The indicators took into consideration are: FDI volume, available labour, potential factors for investment development (infrastructure situation in the region of interest, the administrative apparatus' capacity and the legislative framework). In order to determine the migration of the investment factor, the analysis is performed in correlation with influencing factors, such as: private consumption, public consumption, gross fixed capital formation, export capacity, final import demand, final demand, import of goods, Gross Domestic Product (GDP) and GDP Deflator (GNI). Regarding the employment, the quantification is based on the unemployment dynamics, the migration process, the qualitative indicators from the global competitiveness index (labour market, skills, health and macroeconomic stability) and the consumer price index.

The economic analysis covers the following algorithm:

- the comparative analysis of the analysed indicators;

- the tendency study of the two antagonistic migration phenomena;

- the conceptualization of the proposed economic model;

- raising awareness of the model by relating it to the enhancing factors of the investment development; 
- testing and validating of the model.

The working hypotheses in the development of the model are:

According to some authors (Tombe \& Zhu, 2019), there is a direct correlation between trade, migration and productivity. In the opinion of the authors of this article, this correlation is transposed in hypothesis $\mathrm{H} 1$.

H1: in the context of global trade, the capital migration force acts in the opposite direction to the labour migration force, the intersection between these two antagonistic phenomena representing a driving factor for the regional development;

Other authors (Adedoyin et al., 2021) have analysed the relationship between trade, government performance and migration, showing that migration is relatively negative to trade, but it is primarily negative to government performance. This approach is used in defining $\mathrm{H} 2$ hypotheses.

H2: the capital migration phenomenon is favoured by the infrastructure quality and the costs related to the location of the production capacities and the development of the production, the flexibility of the bureaucratic apparatus and the stability of the legislative framework harmonized with the EU legislation;

Experts (Boghean \& State, 2015) pointed out the connection between FDI and labour productivity in the EU. This correlation recommends the considering of the H3 hypothesis. H3: the labour migration phenomenon is favoured by the increase in unemployment, the volatility of consumer prices and the decrease of GDP / capita;

Other authors (Simionescu, 2016) presented an economic growth model based on economic sustainable growth and FDI during the economic crisis across the EU. Campos and Coricelli (2017) analysed the migration impact on the EU market. These two approaches are the support for defining $\mathrm{H} 4$.

H4: the congruence of the two migration flows is represented by the area with high sustainability and the driving force of the economic development. The size of this area directly reflects the absorption capacity of the welfare by the state in which the labour migration manifests itself with high intensity;

Based on hypotheses $\mathrm{H} 1-\mathrm{H} 4$, we formulate a general hypothesis of the model, namely H5. H5: maximizing the congruence area has a financial leverage effect on the stability of the EU area.

Based on the research objectives and the working hypotheses, the research scheme is defined, as in Figure 1.

Using the algorithm presented in Figure 1, we define the function of the migrant investment fund offer - FDI mig as the surplus of the investment fund left after the fruition of the national competitive advantage, as:

$$
F D I_{\text {mig }}=F D I-F D I_{n a t}=\frac{F D I_{r e q} \cdot G F C}{T N C}-\frac{I m p_{g s}-\operatorname{Exp}_{g s}}{T N C},
$$

where: $F D I_{\text {mig }}$ - migrant investment fund; $F D I$ - investment fund; $F D I_{\text {nat }}$ - investment fund used inside the national economy; $F D I_{\text {req }}$ - final demand; GFC - Gross fixed capital formation; Imp $p_{g s}$ - Import of goods and services; $\operatorname{Exp}_{g s}$ - Export of goods and services; TNC - Total National Consumption (Public Consumption + Private Consumption). 
We define the demand function Migrant Labour Productivity - Lab ${ }_{\text {mig }}$, as the labour productive surplus that is subject to the phenomenon of migration depending on the national capacity of labour absorption and the attractiveness of the national service supply in relation to the external supply, as:

$$
L a b_{\text {mig }}=L a b-L a b_{n a t}=\left(\frac{T N C \cdot U N E_{r}}{1-H I C} \cdot \frac{A g C}{M s}\right)-\left(\frac{P V C \cdot U N E_{r}}{1-H I C} \cdot \frac{A g C}{M s}\right),
$$

where: $L a b_{\text {mig }}$ - Migrant Labour Productivity; Lab - Total Labour Productivity; Lab $b_{\text {nat }}$ - The productivity of the labour force absorbed in the national economy; TNC - Total National Consumption (Public Consumption + Private Consumption); $U N E_{r}-$ Unemployment rate;

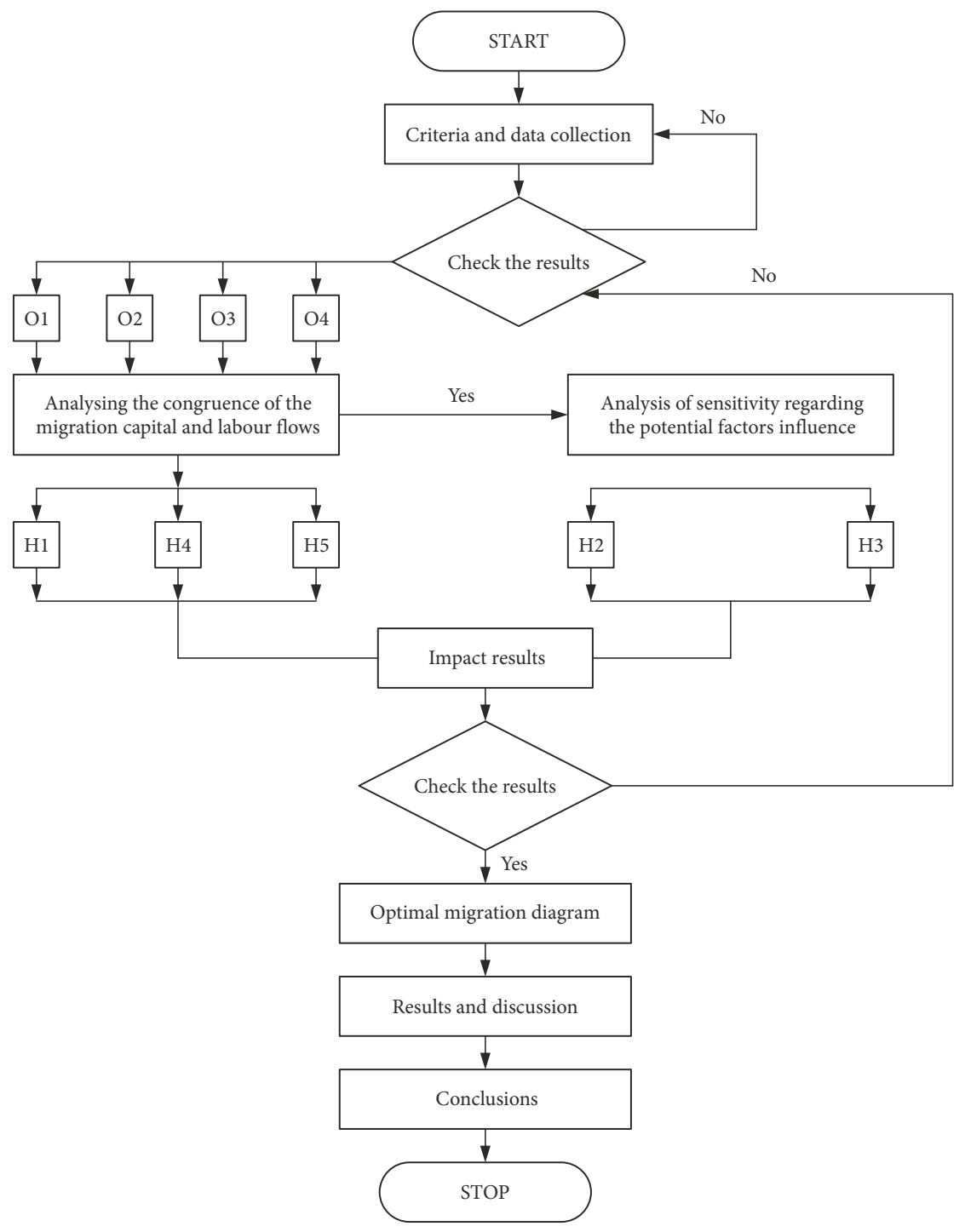

Figure 1. The research process (source: authors' contribution) 
HIC - Harmonized index of consumer prices; $\mathrm{AgC}$ - Aggregate competitively index = The multiplied of the competitiveness indices for the Labour market (Pillar 8 from Global Competitiveness Index), Market size (Pillar 10 from Global Competitiveness Index), Skills (Pillar 6 from Global Competitiveness Index), Health (Pillar 5 from Global Competitiveness Index), Business dynamism (Pillar 11 from Global Competitiveness Index) (Schwab, 2018); Ms Competitiveness index for Macroeconomic stability (Pillar 4 from Global Competitiveness Index); PVC - Private consumption.

We define the congruence of the investment demand function with the labor supply function, as follows:

$$
\begin{aligned}
& (\exists) f(x): R \rightarrow R, x \neq \varnothing ; \\
& f(x)=\Delta\left(F D I_{\text {mig }}(x), L a b_{\text {mig }}(x)\right)=\left(F D I-F D I_{\text {nat }}\right) \cap\left(L a b-L a b_{\text {nat }}\right),
\end{aligned}
$$

where: $f(x)$ - congruence of the investment demand function with the labor supply function; $R$ - the set of real numbers; $x$ - function attribute; $\varnothing$ - the empty set.

This function fulfils the conditions of maximum if and only if the supply function is maximum:

$$
\begin{aligned}
& \max _{n \rightarrow \infty} f(x)=\max _{n \rightarrow \infty}\left(F D I_{\text {mig }}(x), \text { Lab }_{\text {mig }}(x)\right) ; \\
& \max _{n \rightarrow \infty} f(x)=\max _{n \rightarrow \infty}\left(F D I-F D I_{\text {nat }}\right) \cap \max _{n \rightarrow \infty}\left(\text { Lab }- \text { Lab }_{\text {nat }}\right) .
\end{aligned}
$$

The maximum condition is always fulfilled for the demand function, while the supply function tends to the minimum, in the absence of motivational factors (investments in infrastructure, investments in the efficiency of the bureaucratic apparatus, consolidation of the legislative framework).

As a result, there is $\alpha$, defined as the package of motivational factors that determine the optimization of the congruence of the two functions in the European space as the function $\alpha$, because based on convergence policies the impact of motivational factors extends to the values for the European Union:

$$
\propto=A g I s_{E U 27} \cdot A g I n_{E U 27} \cdot A g I T C_{E U 27},
$$

where: $\alpha$ - multiplicative type function with the role of optimizing the FDI absorption in the EU27; $A g I s_{E U 27}$ - EU27 infrastructure competitiveness index (Pillar 2 from Global Competitiveness Index); $A g I_{E U 27}$ - EU27 Institutional Competitiveness Index (Pillar 1 from Global Competitiveness Index); $A g I T C_{E U 27}$ - The competitiveness index of the absorption of technology and communications in the EU27 (Pillar 3 from Global Competitiveness Index);

Such that:

$$
1-\max _{E U 27} \alpha \rightarrow 0
$$

There is $\beta$ defined as the package of motivational factors existing in the country of destination that determines the optimization of the congruence of the two functions in the global space in the form of the $\beta$ function:

$$
\beta=A g I s_{\text {nat }} \cdot A g I n_{n a t} \cdot A g I T C_{n a t},
$$

where: $\beta$ - multiplicative type function with the role of optimizing the global FDI absorption; 
$A g I s_{n a t}$ - Competitiveness index of global infrastructure (Pillar 2 from Global Competitiveness Index); $A g I_{n a t}$ - Competitiveness index of global institutions (Pillar 1 from Global Competitiveness Index); $A g I T C_{n a t}$ - The competitiveness index of the absorption of technology and communications at global level (Pillar 3 from Global Competitiveness Index);

Such that:

$$
1-\max _{\text {nat }} \beta \rightarrow 0 \text { and } \alpha+\beta=1, \alpha>\beta .
$$

It turns out that the function $\mathrm{f}(\mathrm{x})$ is maximized if and only if the supply function Migrant Investment Fund, is maximized according to the relation:

$$
\max _{n \rightarrow \infty} f(x)=\alpha \cdot \max _{n \rightarrow \infty}\left(F D I-F D I_{n a t}\right)+\beta \cdot \max _{n \rightarrow \infty}\left(F D I-F D I_{n a t}\right) .
$$

The optimization of the congruence between the two functions thus becomes possible based on the optimization of motivational and advantageous factors for the European component of the FDI (transposition of the common market principle) according to:

$$
\begin{aligned}
& O P T(f(x))=O P T\left(F D I_{m i g}\right) \cap O P T\left(L a b_{m i g}\right) ; \\
& O P T(f(x))=\alpha \cdot \max _{n \rightarrow \infty}\left(F D I_{m i g}\right)+\beta \cdot \max _{n \rightarrow \infty}\left(F D I_{m i g}\right) .
\end{aligned}
$$

The optimal equation is graphically transposed according to Figure 2.

The congruence represents the optimized area of the two migration flows with high sustainability and the driving force of the economic development.

The proposed theoretical model allows the identification of the optimal area. It is easily adapted to the global or regional economy through the general functions of investment and labor.

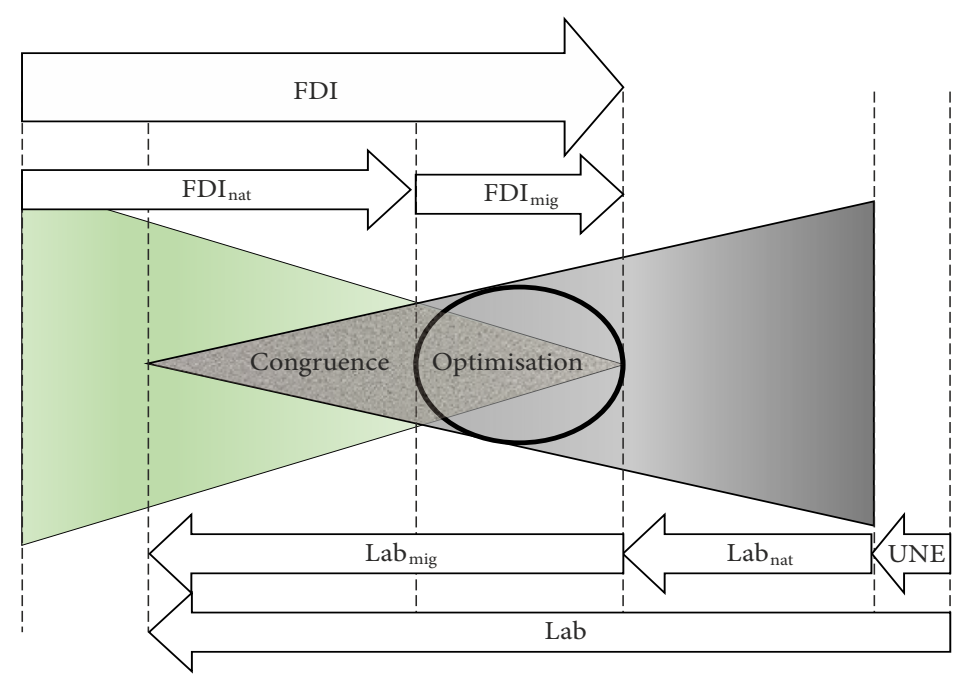

Figure 2. The research process (source: authors' contribution) 


\section{Results and discussion}

In order to implement the proposed model, a dedicated database has been built for the period 2010-2020, using information from Eurostat, The European Commission, the European Parliament and United Nations Organisation (European Commission, 2019b; European Parliament, 2018). In order to ensure data comparability, an exchange rate for Romania of 1 Euro $=4.5$ lei was calculated.

The main indicators used in the model construction concern the consumption components (private + public), quantified for EU and for the 2 Member States taken into discussion. Germany is considered to be FDI donor and labour receiver, while Romania is labour donor and FDI receiver. The prevalence of private consumption is compared with public consumption, for all 3 analysed economic entities, in a proportion of 3:1 or higher, depending on the GDP pivot. From the structure and contribution to EU consumption point of views, there are significant differences between the extremes Germany and Romania, of at least 16:1 on average during the analysed period. The largest gap is recorded at the beginning of the analyzed period (2010). Romania reduced the distance from Germany to 14:1 at the end of the period (2020).

Germany has a share in EU consumption of 20\%, while Romania has $1.2 \%$ and 4 -times smaller population than that of Germany. Making parity in the population, the difference of contribution to European consumption between these two states is 5:1. These data are shown graphically in Appendix - Figure A1.

The second set of analysed indicators targets the capital accumulations at the level of the above 3 economic entities, reflected in the current prices of GDP in 2017 and GNI, which are the basis of the investment process and the flows of labour as phenomena that are the subject of the present research. From GDP point of view, in Table 3, it is noted that the evolution is constantly increasing for the 3 analysed entities with a maximum growth value over the middle of the analysed period (2016-2017), the trend having a tendency to return to the growth rates from the beginning of the period (economic crisis). They foreshadow the cyclicality of the crisis phenomenon under the impact of the new trends manifested in the EU from both economic and political points of view.

As with consumption, GDP accumulations are on average 18 times higher in Germany than in Romania. By eliminating the effect of the population difference, it is found that Germany has 4 times greater GDP accumulation capacity than Romania. Germany's contribution to EU GDP was on average of $21.5 \%$ during the analysed period (see Appendix - Figure A2).

The third analysed indicator evaluates the trade in the region from the exports and imports of goods and services point of view, quantified in a unitary basis at the level of the 3 economic entities at an average contribution of $43 \%$ of GDP, highlighting the superior export capacity for Germany ( $+7.5 \%$ of GDP) and the negative import capacity for Romania (-2.12\% of GDP) (see Appendix - Figure A3).

The final demand is an integrated indicator that shows, on the one hand, the capacity of FDI absorption in the region, and on the other hand, the solidity of the measures to maintain the regional economy in the performance targets assumed at European level. From the final demand point of view, the two poles (Romania and Germany) are at 5-6 times greater difference, the difference which is complemented by the negative trend of the net export in 
Romania, in comparison with the positive trend of the net export in Germany (see Appendix - Figure A4).

In the case of gross fixed capital formation (GFCF) and investments, we notice a predominantly increasing trend for both indicators, of which the GFCF trend is linear, with an average annual net growth of $3 \%$ at EU level, while for investments, the trend is asymptotic, with a turning point in 2015-2018. This situation is reflected in Appendix - Figure A5.

Regarding the asylum applications due to security and economic considerations, there is a clear tendency to increase asylum applications during the analysed period, especially for young people between 18 and 34, who reach 50\% of the total population applying to total asylum applications.

From the security and attractiveness point of view, the EU has proved to be a reference pole in terms of "capturing" asylum seekers through a permissive European policy and oriented towards granting asylum seekers security. At the same time, some economic levers in the EU regarding the social integration of asylum seekers have been changed, by promoting social inclusion policies, eliminating discriminatory treatment and granting equal opportunities (see Table 2).

On the contrary, Romania, whose contribution to the EU GDP is about 1\%, manages to "capture" asylum seekers in the proportion of $0.15 \%$ of the total number of applicants in the EU (see Figure 3).

The analysis of the labour migratory phenomenon cannot be carried out in the absence of the unemployment rate and of the consumption price index analysis, because these 2 indicators directly reflect the options of the migrants regarding the country of destination by providing access to work and the safety of the average daily basket.

As far as the consumer price index is concerned, the situation is unfavorable for Romania, given that Germany has managed to place above the EU average in terms of the consumer price constant over the analysed period. In the case of Romania, the index was $13.5 \%$ at the beginning of this period, recovering in 2016 , to $1.1 \%$, so that, by the consumption policy promoted by the Romanian government, it would again increase to the maximum limit agreed in the EU, of $3.6 \%$. The forecast for 2020 in Romania shows that the consumer price index

Table 2. Asylum labour's trends - persons (source: authors' contribution)

\begin{tabular}{|c|c|c|c|c|c|c|c|c|c|c|}
\hline Zone & Variable & MU & $2010-2013$ & 2014 & 2015 & 2016 & 2017 & 2018 & 2019 & 2020 \\
\hline \multirow{3}{*}{ EU-27 } & $\begin{array}{l}\text { Asylum } \\
\text { applications }\end{array}$ & pers & 431.090 & 626.960 & 1.322 .825 & 1.260 .910 & 705.705 & 1.163 .045 & 1.270 .137 & 1.377 .228 \\
\hline & $\begin{array}{l}\text { Asylum labour } \\
\text { force } 18-34 \mathrm{yr} \text {. }\end{array}$ & pers & 222460 & 335795 & 697200 & 644150 & 362395 & 598015 & 651827 & 705639 \\
\hline & $\begin{array}{l}\text { Asylum labour } \\
\text { force } 35-64 \mathrm{yr} \text {. }\end{array}$ & pers & 86740 & 124490 & 231245 & 209145 & 125175 & 204138 & 222243 & 240347 \\
\hline \multirow{3}{*}{ Romania } & $\begin{array}{l}\text { Asylum } \\
\text { applications }\end{array}$ & pers & 611 & 888 & 1.874 & 1.786 & 1.000 & 1.647 & 1.799 & 1.951 \\
\hline & $\begin{array}{l}\text { Asylum labour } \\
\text { force } 18-34 \mathrm{yr} \text {. }\end{array}$ & pers & 315 & 476 & 988 & 912 & 513 & 847 & 923 & 999 \\
\hline & $\begin{array}{l}\text { Asylum labour } \\
\text { force } 35-64 \text { yr. }\end{array}$ & pers & 123 & 176 & 328 & 296 & 177 & 289 & 315 & 340 \\
\hline \multirow{3}{*}{ Germany } & \begin{tabular}{|l|} 
Asylum \\
applications
\end{tabular} & pers & 209908.98 & 305283.19 & 644118.03 & 613970 & 343626.19 & 566316.98 & 618462.87 & 670608.27 \\
\hline & $\begin{array}{l}\text { Asylum labour } \\
\text { force } 18-34 \text { yr. }\end{array}$ & pers & 108322 & 163507 & 339485 & 313653 & 176460 & 291189 & 317392 & 343594 \\
\hline & $\begin{array}{l}\text { Asylum labour } \\
\text { force } 35-64 \mathrm{yr} \text {. }\end{array}$ & pers & 42236 & 60617 & 112599 & 101838 & 60951 & 99400 & 108216 & 117031 \\
\hline
\end{tabular}


will be $3 \%$, equal to the maximum limit allowed by the EU. This index is scripted, because the masked inflation is estimated to reach in Romania more than $200 \%$ of the EU limit (see Appendix - Figure A6).

As we have shown in the case of asylum seekers, migrant labour is influenced by the economic conditions offered by the state of destination. In opposition the FDI migration targets macroeconomic opportunities, including macroeconomic and policy stability offered by the destination country. In order to quantify these conditions, we used the statistics provided by the World Economic Forum regarding the global competitiveness index reported for Romania, Germany and the EU as a whole (see Table 3).

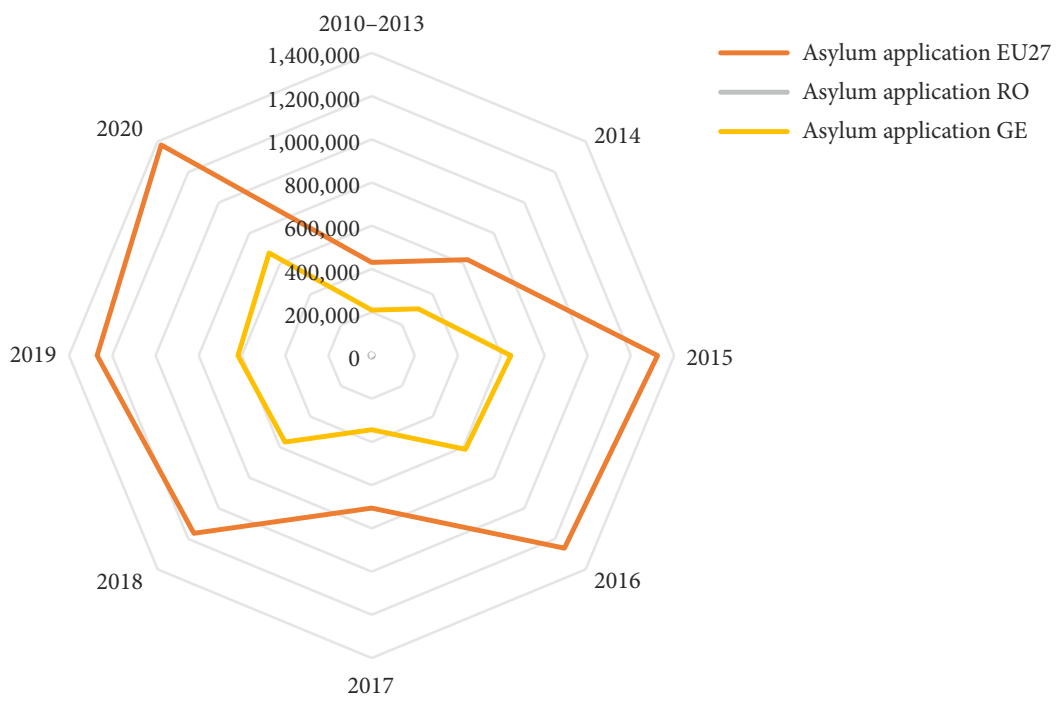

Figure 3. Asylum application's trend (persons) (source: authors' contribution)

Table 3. Competitiveness index (\%) (source: authors' contribution)

\begin{tabular}{|c|c|c|c|}
\hline Competitivity Index & EU-27 & Romania & Germany \\
\hline Institutions & $64.50 \%$ & $58.10 \%$ & $73.50 \%$ \\
\hline Infastructure & $78.70 \%$ & $71.20 \%$ & $90.20 \%$ \\
\hline ICT adoption & $68.00 \%$ & $67.10 \%$ & $69.30 \%$ \\
\hline Macroeconomic stability & $91.80 \%$ & $89.20 \%$ & $100.00 \%$ \\
\hline Health & $90.70 \%$ & $79.80 \%$ & $94.50 \%$ \\
\hline Skills & $74.20 \%$ & $61.80 \%$ & $85.40 \%$ \\
\hline Product market & $62.00 \%$ & $57.30 \%$ & $72.00 \%$ \\
\hline Labour market & $66.20 \%$ & $60.70 \%$ & $74.10 \%$ \\
\hline Financial system & $69.50 \%$ & $51.90 \%$ & $80.20 \%$ \\
\hline Market size & $59.60 \%$ & $64.70 \%$ & $85.80 \%$ \\
\hline Business dynamism & $68.30 \%$ & $60.10 \%$ & $81.60 \%$ \\
\hline Innovation capability & $58.10 \%$ & $39.60 \%$ & $87.50 \%$ \\
\hline
\end{tabular}


At EU level, the impact of the policy misalignment with the performance targets generates a competitiveness gap compared to the strategic poles, such as Germany. As a result, the values on the 12 goals of the global competitiveness index are higher for Germany than for the EU. At the opposite end, Romania has values of the competitiveness index lower than the EU average in most chapters. However, the global competitiveness values are satisfactory (over 65\%) for 5 of the 12 indicators, respectively: infrastructure (due to favourable geographical location), ITC adoption, macroeconomic stability, health and market size. A major disadvantage of FDI in Romania is represented by the excessive bureaucracy of the public institutions (51\%) and the reduced innovation capacity (39.6\%, compared with $87.5 \%$ in Germany), (see Figure 4).

Considering the methodology presented above and the results of data implementation, we proceeded to test the model with the statistical tools made available by the dedicated software IBM-SPSS 25 . The calculated variables generated the following series of data, which were then entered into the IBM-SPSS 25 program. The data series on migration investments $\left(\mathrm{FDI}_{\mathrm{mig}}\right)$ is presented in Table 4.

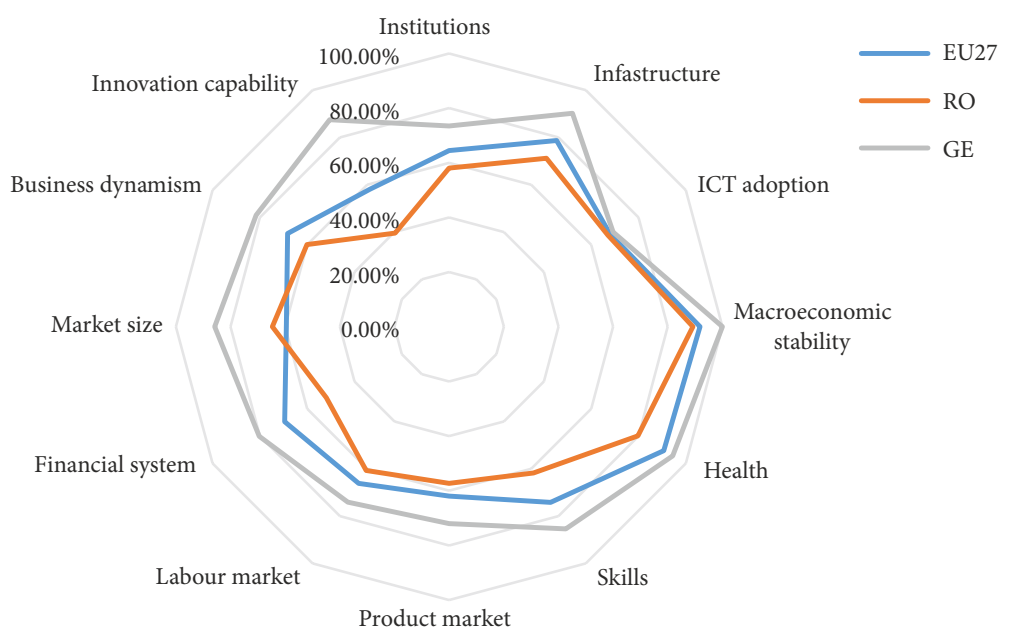

Figure 4. Correlation between analysed indicators (source: authors' contribution)

Table 4. FDI mig (source: authors' contribution)

\begin{tabular}{|c|c|c|c|}
\hline \multirow{2}{*}{ Year } & EU $27-F D I_{m i g}$ & ROMANIA $-F D I_{m i g}$ & ${\text { GERMANY }-F D I_{\text {mig }}}$ \\
\cline { 2 - 4 } & Bn. Euro & Bn. Euro & Bn. Euro \\
\hline $2010-2013$ & 4786.026 & 64.44217 & 264.8165 \\
\hline 2014 & 5010.772 & 67.95437 & 272.8179 \\
\hline 2015 & 5366.78 & 73.42077 & 285.5573 \\
\hline 2016 & 5566.149 & 74.40564 & 311.9338 \\
\hline 2017 & 5820.276 & 76.90292 & 341.6478 \\
\hline 2018 & 6055.141 & 77.11247 & 375.8496 \\
\hline 2019 & 6200.241 & 78.67993 & 400.6304 \\
\hline 2020 & 6361.984 & 80.61434 & 421.4314 \\
\hline
\end{tabular}


The data series regarding the labour is presented in Table 5.

The model that analysed the correlations of the two phenomena (labour migration from less developed Member States and FDI from developed Member States) is based on the curve estimation function and is called fit curve for the regression variables RO - LAB MIG and GE - FDI MIG by the function of forecasting the evolution of cubic linear trend and the growth function with the statistical tests related to the ANOVA model. The number of variables generated by the model is 60 for a $95 \%$ confidence interval, the method of calculating the standard autocorrelation being ACFSE $=$ IND. The statistical significance of the evaluation model of the labour migratory tendency in which the independent variable is RO - LAB MIG, and the dependent variable is GE - FDI MIG, is of $86 \%$, with an estimated standard error of the regression of 0.67 and a high p-value significantly statistically lower than 0.001 . The function of the model on the three tests (linear, cubic, growth) reflects the data series homogeneity and the model validity, the data being polarized on a decreasing trend of the function, which meets the increasing trend of FDI (see Table 6).

Table 5. Labour flows (source: authors' contribution)

\begin{tabular}{|c|c|c|c|c|c|c|c|c|c|}
\hline Indicator & Area & 2010-2013 & 2014 & 2015 & 2016 & 2017 & 2018 & 2019 & 2020 \\
\hline$L a b$ & \multirow[t]{3}{*}{ EU27 } & 252.29 & 255.29 & 241.35 & 224.82 & 206.55 & 173.52 & 166.13 & 161.61 \\
\hline$L a b_{n a t}$ & & 183.90 & 186.13 & 176.31 & 164.55 & 151.58 & 127.52 & 122.08 & 118.88 \\
\hline$L a b_{\text {mig }}$ & & 68.40 & 69.16 & 65.04 & 60.27 & 54.96 & 46.01 & 44.05 & 42.72 \\
\hline$L a b$ & \multirow[t]{3}{*}{ Romania } & 1.28 & 1.33 & 1.15 & 1.05 & 0.97 & 0.90 & 0.91 & 0.92 \\
\hline$L a b_{\text {nat }}$ & & 0.98 & 1.02 & 0.89 & 0.83 & 0.78 & 0.72 & 0.74 & 0.75 \\
\hline$L a b_{\text {mig }}$ & & 0.30 & 0.31 & 0.25 & 0.22 & 0.19 & 0.17 & 0.18 & 0.18 \\
\hline$L a b$ & \multirow[t]{3}{*}{ Germany } & 74.11 & 74.84 & 44.05 & 40.16 & 38.38 & 34.75 & 31.98 & 28.31 \\
\hline$L a b_{\text {nat }}$ & & 54.59 & 55.08 & 32.32 & 29.33 & 28.04 & 25.39 & 23.31 & 20.62 \\
\hline$L a b_{\text {mig }}$ & & 19.52 & 19.75 & 11.73 & 10.84 & 10.34 & 9.36 & 8.67 & 7.68 \\
\hline
\end{tabular}

Table 6. Statistical analysis for dependent variable ln (Ge - Fdi mig) (source: authors' contribution)

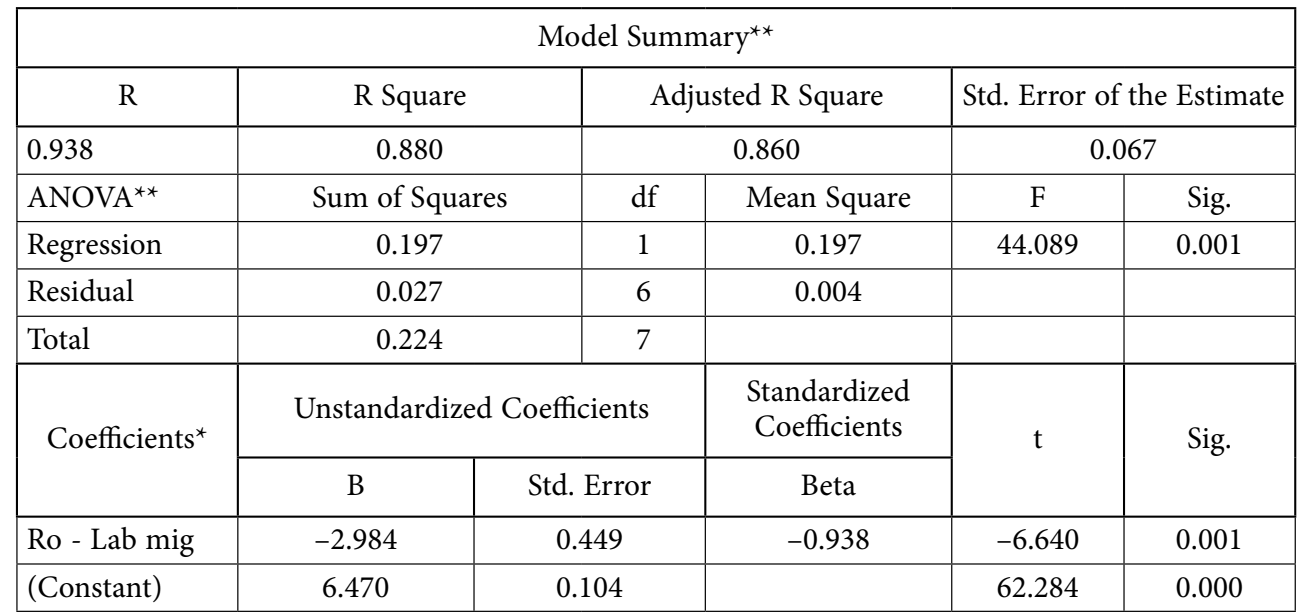

Note ${ }^{\star}$ The dependent variable is $\ln \left(\mathrm{Ge}-\right.$ Fdi mig). ${ }^{*}$ The independent variable is Ro - Lab mig. 
In Table 6, the determination coefficient is significant, which validates the model, and the sum of the squares of the regression variables is significant in the total sum of the squares calculated for the ANOVA test (88\%). The sum of the regression squares is a residue of only $10 \%$, with a freedom degree 6 compared to the regression degree of 1 . The Sig coefficient is less than 0.05 and validates the representativeness of the proposed model. It can be seen from the table of coefficients that the dependent variable has an evolution in dynamics inversely proportional to the Ro - Lab mig regressor $(-2.984)$.

The model that analysed the FDI migration from the developed Member States is based on the curve estimation function and is named for the regression variables GE - FDI MIG and RO - LAB MIG by the forecast function of the evolution of cubic linear trend and the growth function with the related statistical tests of the ANOVA model. The number of variables generated by the model is 60 for a $95 \%$ confidence interval, the method of calculating the standard deviations of autocorrelation being ACFSE = IND. The statistical significance of the FDI migration trend assessment model, in which the independent variable is GE - FDI MIG, and the dependent variable is RO - LAB MIG, is $86 \%$, with an estimated standard error of the regression of 0.90 and high significant $p$-value statistically lower than 0.001 . The function of the model on the three tests (linear, cubic, increasing) reflects the data series homogeneity and the model validity, the data being polarized on a decreasing trend of the FDI function, when the labour migration increases, the slope of deceleration is much higher than in the case of the labour migration according to FDI slope deceleration (see Table 7).

In Table 7, there are the modelling results for the dependent variable ln (Ro - Lab mig). The determination coefficient is significant, which validates the model, and the sum of the regression variables squares is significant in the total sum of the squares calculated for the ANOVA test (88\%). The sum of the regression squares is a residue of only $10 \%$, with a freedom degree of 6 , compared to the regression degree of 1 . The Sig coefficient is less than 0.05 and validates the representativeness of the proposed model. It can be seen from the table of coefficients that the dependent variable has an evolution in dynamics inversely proportional to the regressor Ge - Fdi mig (-0.256).

Table 7. Statistical analysis for dependent variable ln (Ro - Lab mig) (source: authors' contribution)

\begin{tabular}{|c|c|c|c|c|c|}
\hline \multicolumn{6}{|c|}{ Model Summary ${ }^{\star *}$} \\
\hline $\mathrm{R}$ & R Square & \multicolumn{2}{|c|}{ Adjusted R Square } & \multicolumn{2}{|c|}{ Std. Error of the Estimate } \\
\hline 0.938 & 0.880 & \multicolumn{2}{|c|}{0.860} & \multicolumn{2}{|c|}{0.090} \\
\hline ANOVA $^{* *}$ & Sum of Squares & df & Mean Square & $\mathrm{F}$ & Sig. \\
\hline Regression & 0.360 & 1 & 0.360 & 43.992 & 0.001 \\
\hline Residual & 0.049 & 6 & 0.008 & & \\
\hline Total & 0.409 & 7 & & & \\
\hline \multirow[t]{2}{*}{ Coefficients* } & \multicolumn{2}{|c|}{ Unstandardized Coefficients } & $\begin{array}{c}\text { Standardized } \\
\text { Coefficients }\end{array}$ & \multirow[t]{2}{*}{$\mathrm{t}$} & \multirow[t]{2}{*}{ Sig. } \\
\hline & B & Std. Error & Beta & & \\
\hline Ge - Fdi mig & -0.004 & 0.001 & -0.938 & -6.633 & 0.001 \\
\hline (Constant) & -0.256 & 0.193 & & -1.326 & 0.233 \\
\hline
\end{tabular}

Notes ${ }^{\star}$ The dependent variable is $\ln \left(\right.$ Ro - Lab mig). ${ }^{*}$ The independent variable is Ge - Fdi mig. 
From the comparison of the two evolution trends of the phenomena, it results that the labour migration has a more direct effect on stopping the FDI migration to the destination area from where the labour migration takes place, while the FDI migration is appreciated by the labour force as having volatile results on welfare, a result confirmed by the difference in the deceleration slope of the two presented above growth models. The optimization function encounters the FDI migration compared to the labour migration, the area that generates on the graph a buffer intersection of the two trends of the antagonistic phenomena that can be optimized by correcting the conditions that influence the slope, respectively macroeconomic factors, administrative capacity, legislation, the infrastructure for FDI, and the reduction of the unemployment rate, the maintenance of the inflation target, the stability of the social climate for the labour, as well. This intersection coincides with the intersection shown in Figure 2, in the methodology section of this paper (see Figure 5).

Several authors (Boghean \& State, 2015; Simionescu, 2016; Josifidis et al. 2014; Lazutka et al., 2018) showed the existence of a direct correlation between FDI and labour productivity, an aspect that we have currently designed in our analysis.

Other authors (Pegkas, 2015; Ebell et al., 2016; Tang, 2017; Serban et al., 2020) study the relationship between FDI and the economic growth, which becomes an effect for the migration model (MILM) from our approach.

The regional dimension is approached (Antonescu, 2015; Paunica et al., 2018; Comes et al., 2018; Lewandowska \& Stopa, 2020) in order to highlight the disparities between the European states. This aspect is incorporated in our research when we analyse the well-being-relocation-allocation paradigm.

A current European case (Brexit) allowed a transposition of the EU28 reality in terms of the labour crisis, which is currently affecting the UK labor market (Bruno et al., 2017; Dhingra et al., 2018). This issue must also be monitored at EU27 level in order to prevent the possible effects of a disturbing phenomenon (restricting the labour's free movement on

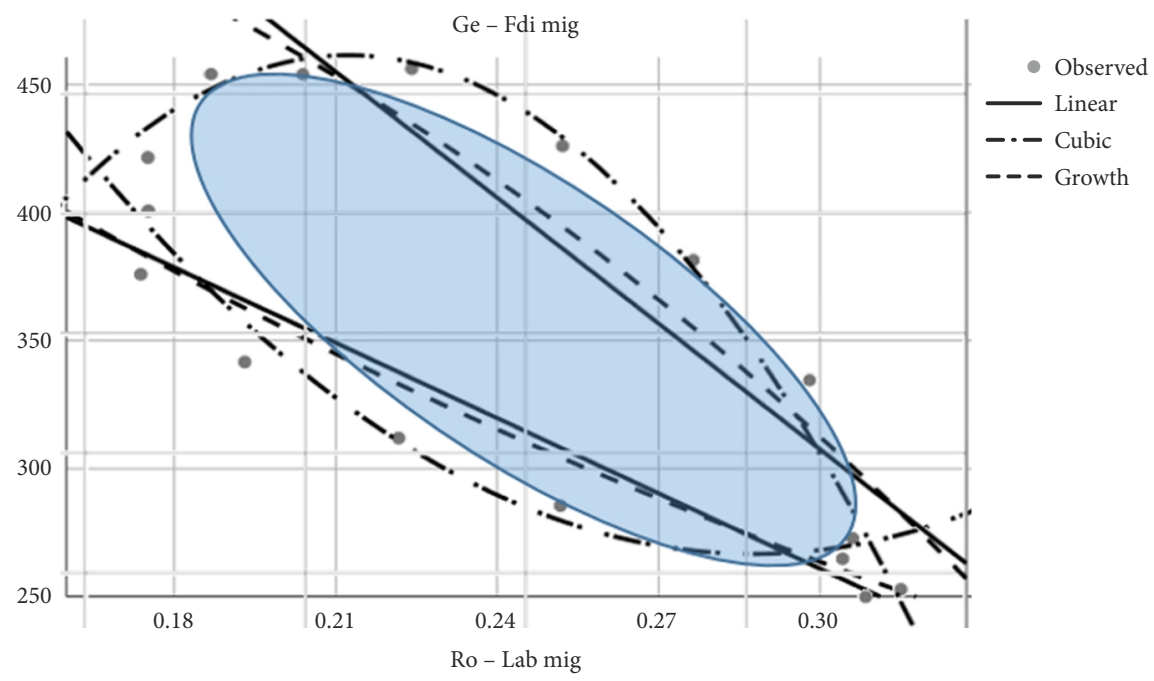

Figure 5. The FDI-labour correlation optimization process (source: authors' contribution) 
various criteria). The consequences may be tempered if the proposed conclusions of the current study would be incorporated into the European economic development policies.

A study relevant to the field studied (Baškot, 2020) highlighted the segregation by age groups of migrants able to relocate within the EU. The author appreciates a weaker connection between labour migration and FDI, an aspect that has been readjusted by our study. The same idea is formulated by Mihi-Ramirez et al. (2019).

In order to verify the objectives and working hypotheses, we turn to the following scientific argument:

O1: studying the specialized literature in order to identify possible models to assess the correlation between the migratory capital and labour phenomena. Through the study of the specialized literature, we have found that the efforts of comparative analysis of FDI and labour migration flows have intensified during the last 5 years, the researchers analysing this complex phenomenon (antagonistic) through the models of economic growth and the realities of the current context (commercial war, Brexit, economic recession, etc.). There is a significant scientific material in the field that addresses both the centralization segment by meta-analysis of the previous studies and the statistical test for analysing the correlations between the two antagonistic phenomena, this being the Literature review subject from the present paper.

\section{O2: the conceptualization of the statistical correlation model;}

H1: in the context of global trade, the capital migration force acts in the opposite direction to the labour migration force, the intersection between these two antagonistic phenomena representing a driving factor for the regional development. Based on the specialized literature analysis, we conceptualized an economic model that was theoretically and practically argued, through the case study, of the phenomenon found at the level of two Member States, of which one developed and one less developed, for which they were tested in dynamics of the evolution of the two antagonistic phenomena, obtaining a statistically valid model that demonstrates the $\mathrm{H} 1$ calculation hypothesis.

\section{O3: connecting model to the potential investment development factors;}

H2: the capital migration phenomenon is favoured by the infrastructure quality and the costs related to the location of the production capacities and the development of the production, the flexibility of the bureaucratic apparatus and the stability of the legislative framework harmonized with the EU legislation;

H3: the labour migration phenomenon is favoured by the increase in unemployment, the volatility of consumer prices and the decrease of GDP / capita. The model was elaborated taking into account the factors favouring the investments development, using for this purpose the classification on the 12 chapters of the global competitiveness indexes for the entities included in the present study. This information was introduced in the methodological argumentation part (in the antagonistic functions being introduced correction effects of the favouring FDI and labour factors) through the components global competitiveness index, unemployment rate and the consumer price index. The model connection to the favouring 
factors was proved to reach the statistical optimum demonstrated by the tests performed during the data modelling.

O4: an impact study to optimize the congruent use of migratory capital and labour as an engine for regional economic development.

H4: the congruence of the two migration flows is represented by the area with high sustainability and the driving force of the economic development. The size of this area directly reflects the absorption capacity of the welfare by the state in which the labour migration manifests itself with high intensity;

H5: maximizing the congruence area has a financial leverage effect on the stability of the EU area. The optimization function generated by the flattening of the surface curves (as shown in Figures 2 and 10), shows that the proposed model has a financial leverage effect on the EU stability in terms of optimizing the FDI attracting factors and increasing the labour welfare in the Member States.

By demonstrating the objectives and working hypotheses, we have developed a new approach regarding the triple connection FDI-labor-economic development, based on the economic environment reality. This approach allows the calculation of the optimized area of investment and labor flows with an impact on economic growth both for the countries at the top of the economic ranking of an area and for the emerging economies in that area. This approach allows decision makers to access an easy tool for sustainable economic growth forecasting.

\section{Conclusions}

The present study started from the premise of creating a tool for assessing welfare by connecting the antagonistic flows of FDI and labour in the EU. This premise was developed by the authors through an economic optimization model, a model that proved valid in the statistical tests performed for 2 Member States (Germany and Romania) also located in antagonistic positions of economic growth. The proposed instrument in this paper can be successfully implemented by developing states, effectively quantifying the welfare gap, assessed on the basis of the deficient implementation of factors favouring FDI and stopping labour migration.

We can say that the model, as thought, is not limited to the EU alone, both flows can be extrapolated to global trade and global labour migration.

On the other hand, the proposed model in this paper can be a valuable tool for the macro and regional decision makers. Moreover, it can influence the labour and emigration policies.

Taking into account the main conclusions of our analysis, the policymakers could improve European policies on the labour and capital free movement by reshaping the financial allocations on the European human capital and FDI development programmes. This would intrinsically contribute to a better European development.

The limits of the study aim at the regional character of the dynamics of the two phenomena (FDI and migration) and there may be significant characteristics in the case of other regions that influence the vector structure of the migration-FDI interconnection. 
The further development of this research will consider the identification of regional corrections necessary for the global transposition of the vector indicator.

The analysis was carried out over a relevant period of time and generated pertinent conclusions regarding the correlation between the two antagonistic phenomena that could be optimized by improving the administrative apparatus and increasing the welfare in the region.

\section{References}

Adedoyin, F. F., Bello, A. A., Abubakar, I. F., \& Agabo, T. J. (2021). How does governance factors influence the trade impact of migration and capital flows in the EU? Journal of Public Affairs, 21(2), e2207. https://doi.org/10.1002/pa.2207

Alamá-Sabater, L., Heid, B., Jiménez-Fernández, E., \& Márquez-Ramos, L. (2017). FDI in Space revisited: The role of spillovers on Foreign Direct Investment within the European Union. Growth and Change, 48(3), 390-408. https://doi.org/10.1111/grow.12173

Antonescu, D. (2015). Empirical analysis of Foreign Direct Investments at NUTS 2 region, in European Union and Romania. Procedia Economics and Finance, 22, 681-689. https://doi.org/10.1016/S2212-5671(15)00284-1

Baškot, B. (2020). Capital flows impact on labor market: how do FDIs and remittances effect youth employment in Bosnia and Herzegovina? Economic Research-Ekonomska Istraživanja, 33(1), 2633 2647. https://doi.org/10.1080/1331677X.2020.1761418

Boghean, C., \& State, M. (2015). The relation between Foreign Direct Investments (FDI) and labour productivity in the European Union Countries. Procedia Economics and Finance, 32, 278-285. https://doi.org/10.1016/S2212-5671(15)01392-1

Bolívar, L. M., Casanueva, C., \& Castro, I. (2019). Global Foreign Direct Investment: A network perspective. International Business Review, 28(4), 696-712. https://doi.org/10.1016/j.ibusrev.2019.01.007

Bruno, R. L., Campos, N. F., Estrin, S., \& Tian, M. (2017). Foreign Direct Investment and the relationship between the United Kingdom and the European Union. In N. F. Campos \& F. Coricelli (Eds.), The economics of UK-EU relations: From the treaty of Rome to the vote for Brexit (pp. 139-173). Springer International Publishing. https://doi.org/10.1007/978-3-319-55495-2_6

Bruno, R. L., \& Cipollina, M. (2018). A meta-analysis of the indirect impact of foreign direct investment in old and new EU member states: Understanding productivity spillovers. The World Economy, 41(5), 1342-1377. https://doi.org/10.1111/twec.12587

Camarero, M., Gómez-Herrera, E., \& Tamarit, C. (2018). New evidence on trade and FDI: How large is the Euro Effect? Open Economies Review, 29(2), 451-467. https://doi.org/10.1007/s11079-018-9479-y

Campos, N. F., \& Coricelli, F. (2017). The economics of UK-EU relations: From the treaty of Rome to the vote for Brexit. Springer International Publishing. https://doi.org/10.1007/978-3-319-55495-2

Comes, C.-A., Bunduchi, E., Vasile, V., \& Stefan, D. (2018). The impact of Foreign Direct Investments and remittances on economic growth: A case study in Central and Eastern Europe. Sustainability, 10(1). https://doi.org/10.3390/su10010238

Delevic, U., \& Heim, I. (2017). Institutions in transition: Is the EU integration process relevant for inward FDI in transition European economies? Eurasian Journal of Economics and Finance, 5, 16-32. https://doi.org/10.15604/ejef.2017.05.01.002

Dellis, K., Sondermann, D., \& Vansteenkiste, I. (2017). Determinants of FDI inflows in advanced economies: Does the quality of economic structures matter? European Central Bank (ECB), https://doi.org/10.2139/ssrn.2990996 
Dhingra, S., Ottaviano, G., Rappoport, V., Sampson, T., \& Thomas, C. (2018). UK trade and FDI: A post-Brexit perspective. Papers in Regional Science, 97(1), 9-24. https://doi.org/10.1111/pirs.12345

Ebell, M., Hurst, I., \& Warren, J. (2016). Modelling the long-run economic impact of leaving the European Union. Economic Modelling, 59, 196-209. https://doi.org/10.1016/j.econmod.2016.06.020

European Commission. (2019a). EU Foreign Direct Investment flows in 2018. https://ec.europa.eu/eurostat/web/products-eurostat-news/-/DDN-20190717-1 ?inheritRedirect=true\&redirect $=\% 2$ Feuro stat $\% 2 \mathrm{~F}$

European Commission. (2019b). European Economic Forecast. Spring 2014 (Luxembourg Publications Office, Ed., Spring 2014, Vol. 3217). European Economy Institutional Papers.

European Parliament. (2018). Migration and asylum: A challenge for Europe. http://www.europarl.europa.eu/RegData/etudes/PERI/2017/600414/IPOL_PERI(2017)600414_EN.pdf

Hanclova, J., Doucek, P., Fischer, J., \& Vltavska, K. (2015). Does ICT capital affect economic growth in the EU-15 and EU-12 countries? Journal of Business Economics and Management, 16(2), 387-406. https://doi.org/10.3846/16111699.2012.754375

Josifidis, K., Supic, N., Pucar, E. B., \& Srdic, S. (2014). Labour migration flows: EU8+2 vs EU-15. Journal of Business Economics and Management, 15(1), 41-55.

https://doi.org/10.3846/16111699.2013.841283

Lazutka, R., Juška, A., \& Navicke, J. (2018). Labour and capital under a neoliberal economic model: Economic growth and demographic crisis in Lithuania. Europe-Asia Studies, 70(9), 1433-1449. https://doi.org/10.1080/09668136.2018.1525339

Lewandowska, A., \& Stopa, M. (2020). The impact of innovative professional qualifications on the sense of employment security: Evidence from Poland. Economics and Sociology, 13, 72-83. https://doi.org/10.14254/2071-789X.2020/13-3/5

Martínez-San Román, V., Bengoa, M., \& Sánchez-Robles, B. (2016). Foreign direct investment, trade integration and the home bias: Evidence from the European Union. Empirical Economics, 50(1), 197-229. https://doi.org/10.1007/s00181-015-0942-y

Meunier, S. (2017). Integration by stealth: How the European Union gained competence over Foreign Direct Investment. JCMS: Journal of Common Market Studies, 55(3), 593-610. https://doi.org/10.1111/jcms.12528

Mihi-Ramirez, A., Arteaga-Ortíz, J., \& Ojeda-González, S. (2019). The international movements of capital and labour: A study of Foreign Direct Investment and migration flows. Entrepreneurial Business and Economics Review, 7(3), 143-160. https://doi.org/10.15678/EBER.2019.070308

Paul, J., \& Feliciano-Cestero, M. M. (2021). Five decades of research on foreign direct investment by MNEs: An overview and research agenda. Journal of Business Research, 124, 800-812. https://doi.org/10.1016/j.jbusres.2020.04.017

Paunica, M., Manole, A., Motofei, C., \& Tanase, G. L. (2018). The globalization in the actual context of the European Union economy. Proceedings of the International Conference on Business Excellence, 12(1), 739-750. https://doi.org/10.2478/picbe-2018-0066

Pegkas, P. (2015). The impact of FDI on economic growth in Eurozone countries. The Journal of Economic Asymmetries, 12(2), 124-132. https://doi.org/10.1016/j.jeca.2015.05.001

Pradhan, R., Arvin, M. B., Bahmani, S., \& Hall, J. H. (2019). Attaining economic growth through financial development and foreign direct investment. Journal of Economic Studies, 46(6), 1201-1223. https://doi.org/10.1108/JES-04-2018-0136

Raza, S. (2015). Foreign Direct Investment, workers' remittances and private savings in Pakistan: An ARDL bound testing approach. Journal of Business Economics and Management. 16(6), 1216-1234. https://doi.org/10.3846/16111699.2013.792867 
Rong, S., Liu, K., Huang, S., \& Zhang, Q. (2020). FDI, labor market flexibility and employment in China. China Economic Review, 61, 101449. https://doi.org/10.1016/j.chieco.2020.101449

Schwab, K. (2018). The Global Competitiveness Report 2018. World Economic Forum.

Serban, A. C., Aceleanu, M., Dospinescu, A., Tirca, D.-M., \& Novo-Corti, M. I. (2020). The impact of EU immigration on economic growth through the skill composition channel. Technological and Economic Development of Economy, 26(2), 479-503. https://doi.org/10.3846/tede.2020.11954

Simionescu, M. (2016). The relation between economic growth and foreign direct investment during the economic crisis in the European Union. Zbornik Radova Ekonomskog Fakulteta u Rijeci / Proceedings of Rijeka School of Economics, 34. https://doi.org/10.18045/zbefri.2016.1.187

Tan, B. W., Goh, S. K., \& Wong, K. N. (2016). The effects of inward and outward FDI on domestic investment: Evidence using panel data of ASEAN-8 countries. Journal of Business Economics and Management, 17(5), 717-733. https://doi.org/10.3846/16111699.2015.1114515

Tang, D. (2017). The determinants of European Union (EU) Foreign Direct Investments in the EU countries from Central and Eastern Europe during 1994-2012. Comparative Economic Research. Central and Eastern Europe, 20(1), 75-99. https://doi.org/10.1515/cer-2017-0005

Tombe, T., \& Zhu, X. (2019). Trade, migration, and productivity: A quantitative analysis of China. American Economic Review, 109(5), 1843-1872. https://doi.org/10.1257/aer.20150811

Yavas, B. F., \& Malladi, R. K. (2020). Foreign direct investment and financial markets influences: Results from the United States. The North American Journal of Economics and Finance, 53, 101182. https://doi.org/10.1016/j.najef.2020.101182 


\section{APPENDIX}

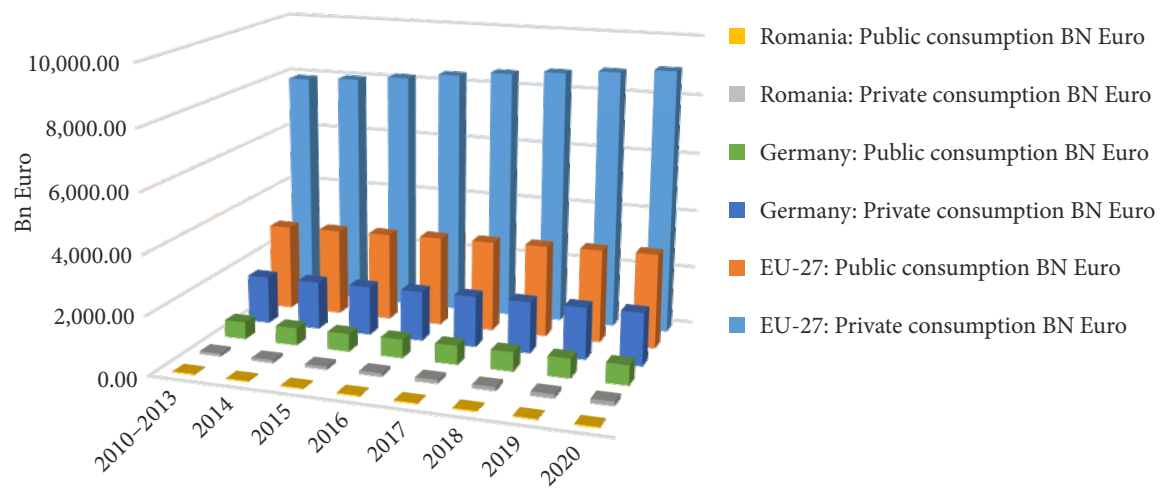

Figure A1. Consumption's trend on components: private and public (source: authors' contribution)

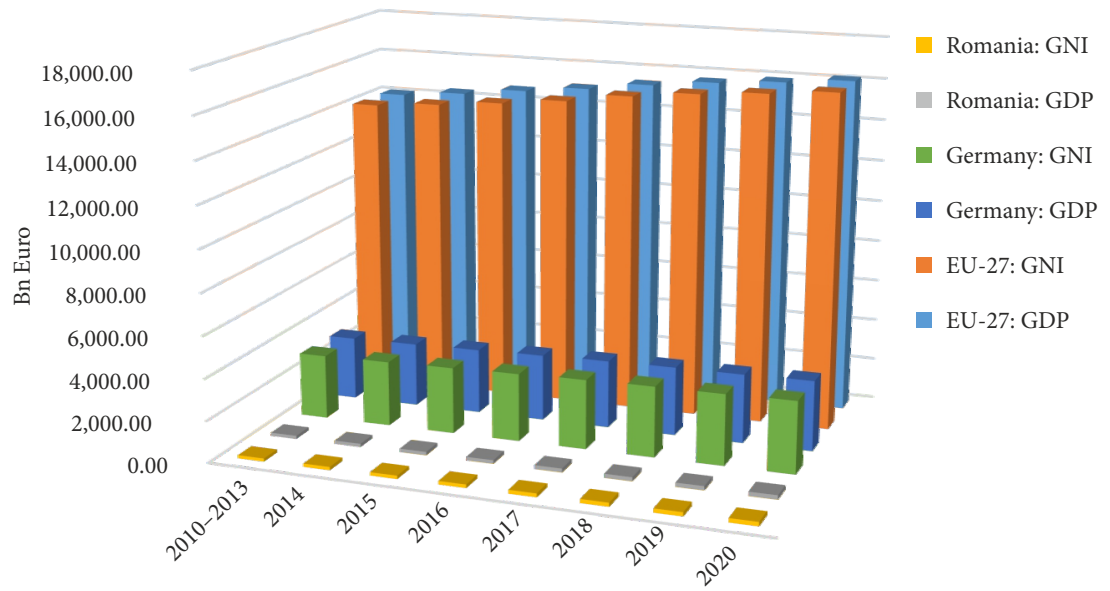

Figure A2. GDP's trend (source: authors' contribution)
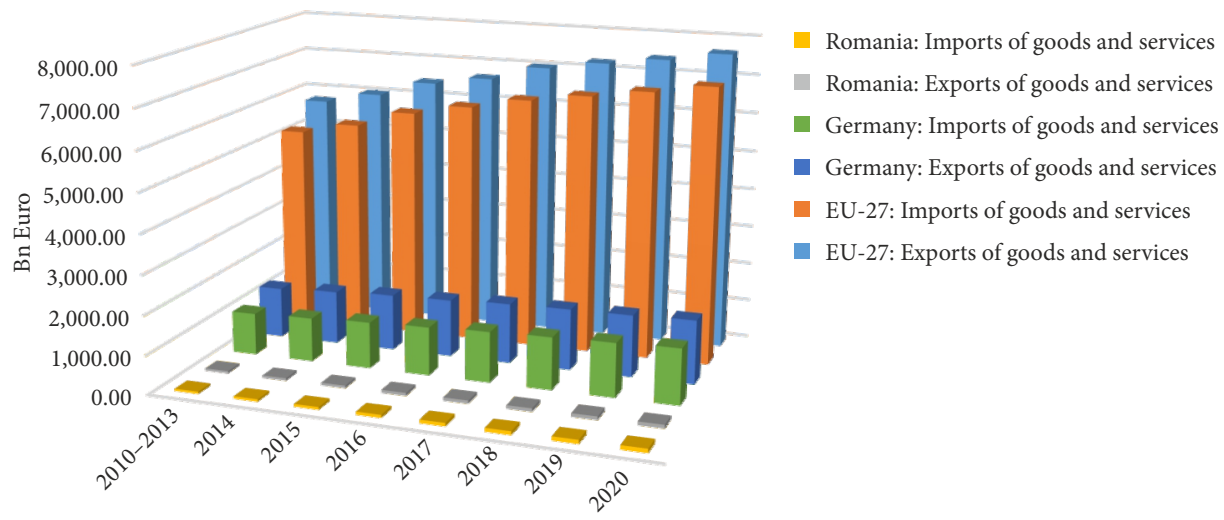

Figure A3. International trade's trend (source: authors' contribution) 


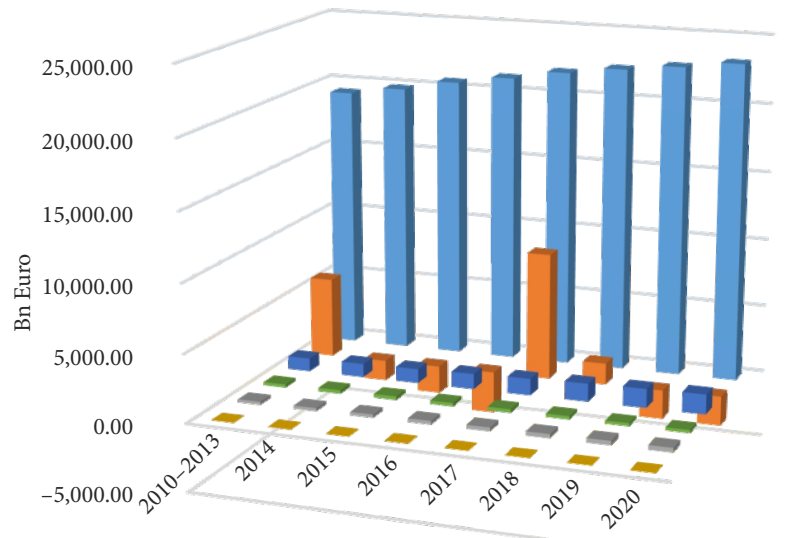
Romania: Net exports
- Romania: Final demand
Germany: Net exports
- Germany: Final demand
EU-27: Net exports
EU-27: Final demand

Figure A4. Final demand's trend (source: authors' contribution)

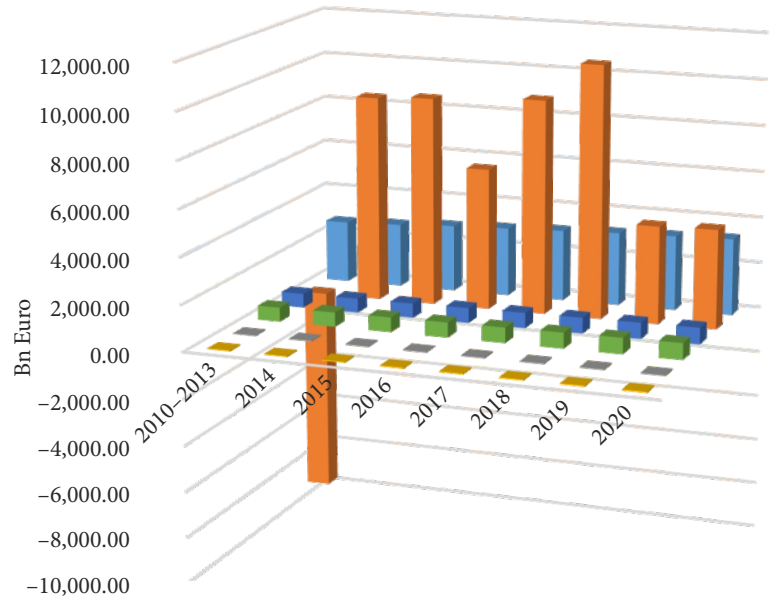
- Romania: Investment
- Romania: Gross fixed capital formation
- Germany: Investment
- Germany: Gross fixed capital formation
EU-27: Investment
- EU-27: Gross fixed capital formation

Figure A5. GFCF and Investment's connection (source: authors' contribution)

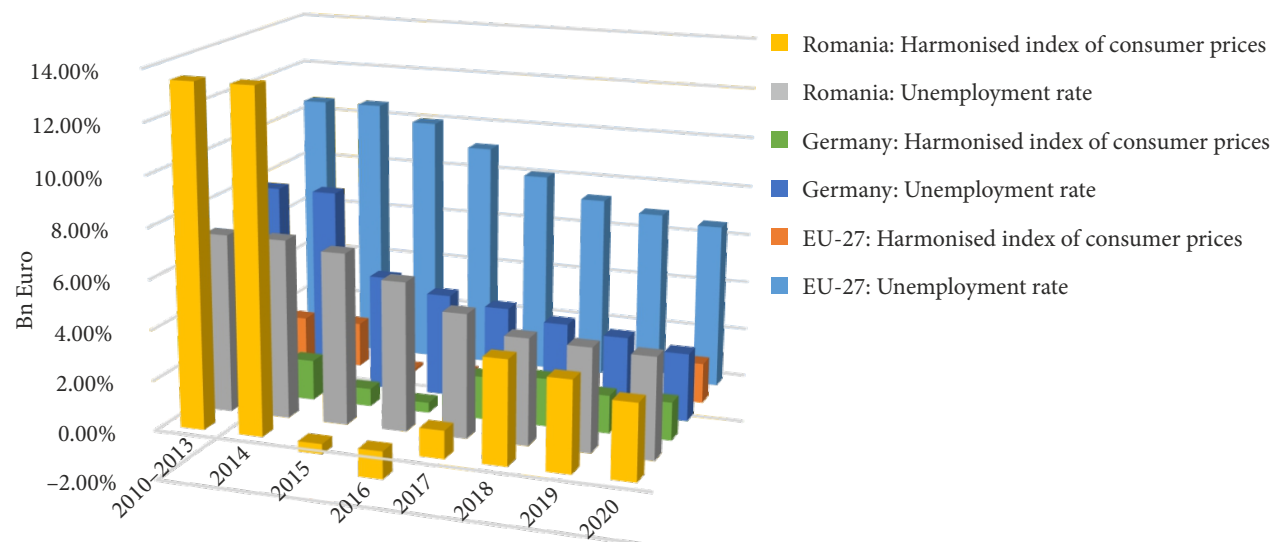

Figure A6. Correlation between unemployment rate and harmonised index of consumer prices (source: authors' contribution) 